\title{
Evolution of biomolecular loadings along a major river system
}

\author{
Chantal V. Freymond ${ }^{\mathrm{a}, *}$, Nicole Kündig ${ }^{\mathrm{a}}$, Courcelle Stark ${ }^{\mathrm{a}, \mathrm{b}}$, Francien Peterse ${ }^{\mathrm{a}, \mathrm{c}}$, \\ Björn Buggle ${ }^{\mathrm{a}}$, Maarten Lupker ${ }^{\mathrm{a}}$, Michael Plötze ${ }^{\mathrm{d}}$, Thomas M. Blattmann ${ }^{\mathrm{a}}$, \\ Florin Filip $^{\mathrm{e}, \mathrm{f}}$, Liviu Giosan ${ }^{\mathrm{g}}$, Timothy I. Eglinton ${ }^{\mathrm{a}}$ \\ ${ }^{a}$ Geological Institute, ETH Zürich, Sonneggstrasse 5, 8092 Zürich, Switzerland \\ ${ }^{\mathrm{b}}$ Department of Geosciences, Smith College, Northampton, MA 01063, USA \\ ${ }^{\mathrm{c}}$ Department of Earth Sciences, Utrecht University, Heidelberglaan 2, 3584 CS Utrecht, Netherlands \\ ${ }^{\mathrm{d}}$ Institute for Geotechnical Engineering, ETH Zürich, Stefano-Franscini-Platz 3, 8093 Zürich, Switzerland \\ ${ }^{\mathrm{e}}$ Institute for Fluvial and Marine Systems, Str. Olari, Nr. 7, Sector 2, Bucharest, Romania \\ ${ }^{\mathrm{f}}$ Fad Smart Technology srl, Sector 2, Bucharest, Romania \\ ${ }^{\mathrm{g}}$ Geology \& Geophysics Department, Woods Hole Oceanographic Institution, 86 Water Street, Woods Hole, MA 02543, USA
}

Received 27 April 2017; accepted in revised form 9 December 2017; available online 15 December 2017

\begin{abstract}
Understanding the transport history and fate of organic carbon (OC) within river systems is crucial in order to constrain the dynamics and significance of land-ocean interactions as a component of the global carbon cycle. Fluvial export and burial of terrestrial $\mathrm{OC}$ in marine sediments influences atmospheric $\mathrm{CO}_{2}$ over a range of timescales, while river-dominated sedimentary sequences can provide valuable archives of paleoenvironmental information. While there is abundant evidence that the association of organic matter $(\mathrm{OM})$ with minerals exerts an important influence on its stability as well as hydrodynamic behavior in aquatic systems, there is a paucity of information on where such associations form and how they evolve during fluvial transport. Here, we track total organic carbon (TOC) and terrestrial biomarker concentrations (plant wax-derived long-chain fatty acids (FA), branched glycerol dialkyl glycerol tetraethers (brGDGTs) and lignin-derived phenols) in sediments collected along the entire course of the Danube River system in the context of sedimentological parameters. Mineral-specific surface area-normalized biomarker and TOC concentrations show a systematic decrease from the upper to the lower Danube basin. Changes in OM loading of the available mineral phase correspond to a net decrease of $70-80 \%$ of different biomolecular components. Ranges for biomarker loadings on Danube River sediments, corresponding to $0.4-1.5 \mu \mathrm{g}_{\mathrm{FA}} / \mathrm{m}^{2}$ for long-chain $\left(n-\mathrm{C}_{24-32}\right)$ fatty acids and $17-71 \mathrm{ng}_{\mathrm{brGDGT}} / \mathrm{m}^{2}$ for brGDGTs, are proposed as a benchmark for comparison with other systems. We propose that normalizing TOC as well as biomarker concentrations to mineral surface area provides valuable quantitative constraints on $\mathrm{OM}$ dynamics and organo-mineral interactions during fluvial transport from terrigenous source to oceanic sink.
\end{abstract}

(C) 2017 Elsevier Ltd. All rights reserved.

Keywords: Danube River; Plant wax fatty acid; brGDGT; Lignin; Organic carbon; Mineral surface area

\section{INTRODUCTION}

\footnotetext{
* Corresponding author.

E-mail address: Chantal.Freymond@erdw.ethz.ch (C.V.
} Freymond).
Rivers form a key connection between continental and marine carbon pools, exporting $210 \mathrm{Mt}$ of dissolved organic carbon (DOC) and $170 \mathrm{Mt}$ particulate organic carbon (POC) annually (Ludwig et al., 1996). Marine burial of 
terrestrial biospheric carbon in fluvially-derived sediments exerts strong control on the atmospheric $\mathrm{O}_{2} / \mathrm{CO}_{2}$ balance (Burdige, 2005; Berner, 2006), and can yield continuous records of past continental vegetation and climate dynamics. Constraints on the origin and evolution of biospheric organic carbon (OC) signals transported by rivers is a necessary prerequisite for comprehensive understanding of the manner in which past and present variations in the amount and composition of terrestrially-derived OC reaching and accumulating in ocean sediments reflects drainage basin dynamics (Blair et al., 2004).

A major fraction of riverine POC is associated with mineral particles (Keil et al., 1997; Keil and Mayer, 2014), particularly fine-grained minerals (e.g. phyllosilicates) due to their large surface area (SA) and sorptive capacity (Keil and Mayer, 2014). Close associations between $\mathrm{OM}$ and high SA mineral phases are known to develop in soils (Sorensen, 1981; Baldock and Skjemstad, 2000; von Lützow et al., 2006), where the latter have been suggested to serve a stabilizing role, protecting OC from further degradation (von Lützow et al., 2006) and thereby slowing carbon turnover (e.g. Torn et al., 1997; Vogel et al., 2015).

Upon erosion of mineral soils and outcropping rock formations, particulate matter is introduced to and transported within river catchments, and ultimately discharged to the ocean. Due to their hydrodynamic properties, finegrained high-SA minerals predominately contribute to the amount of suspended OC that is transported from land to ocean (Tesi et al., 2016). Several studies report a positive correlation between total organic carbon content (TOC) and SA in river sediments (Keil et al., 1997; Galy et al., 2008; Tao et al., 2015; Vonk et al., 2015) as well as in river-dominated continental margin sediments (e.g., Mayer et al., 1988; Mayer, 1994; Goni et al., 2003; Blair and Aller, 2012). However, few studies have investigated the evolution of OC loadings (TOC/SA ratios) along the axis of a river system. Keil et al. (1997) found no systematic variation in TOC/SA loading on suspended particulate matter among three sampling locations from the lower $1800 \mathrm{~km}$ of the Amazon River and two delta samples, and suggested that suspended sediments transport OC at similar loadings throughout the Amazon catchment. Vonk et al. (2015), on the other hand, observed a decrease in TOC loadings during riverine sediment transport through the Mackenzie delta, coupled with preferential deposition of coarser fractions. A recent synthesis of data from river-dominated continental margin sediments revealed that OC loadings generally fall in the range between 0.4 and $1 \mathrm{mg}$ oc $/ \mathrm{m}^{2}$, with higher $\left(>1 \mathrm{mgoc} / \mathrm{m}^{2}\right)$ and lower $\left(<0.4 \mathrm{mg}\right.$ oc $\left./ \mathrm{m}^{2}\right)$ loadings interpreted in terms of shorter and longer oxygen exposure times prior and subsequent to deposition, respectively (Blair and Aller, 2012).

While organo-mineral interactions appear to exert a key influence on OM dynamics in soils, fluvial particles, and river-dominated ocean sediments, the extent to which mineral-associated $\mathrm{OM}$ moves conservatively from source to sink, or evolves during transit remains unclear due to other confounding processes that challenge interpretation of these relationships. One complication is that erosion of
OC-rich sedimentary rocks adds $\mathrm{C}$ that is intrinsic to the particles and unrelated to mineral surface loadings of river sediments. Further, variations in flow conditions and associated hydrodynamic sorting of particles according to grain size and other properties (density, shape) influence the OC concentrations in aquatic sediments, rendering it challenging to evaluate the fate of $\mathrm{OM}$ cascading through the soil-river-ocean continuum.

With respect to the latter issue, mineral-specific SA may serve as a promising property against which to normalize OC abundance (Hedges and Keil, 1995; Keil et al., 1997), thereby obviating OC concentration variations driven by hydrodynamic processes. In order to more directly trace the fate of terrestrial OM and quantify potential changes in loadings, additional diagnostic power is needed. Source-specific biomolecular marker compounds have proven valuable as diagnostic tracers of OM inputs to soils, river and ocean sediments (e.g. Galy et al., 2011; Tesi et al., 2014; Griepentrog et al., 2015), enabling signals of vegetation and soil carbon to be traced free of interference from other carbon sources (e.g., petrogenic inputs, withinriver productivity) (Eglinton and Eglinton, 2008; Thevenot et al., 2010; Schouten et al., 2013). As such, biomarker abundances, distributions and isotopic compositions in river-influenced sedimentary sequences now form the basis for numerous paleoenvironmental and paleoclimatological studies (e.g., Kastner and Goni, 2003; Schefuss et al., 2005; Weijers et al., 2007; Bendle et al., 2010; Sanchi et al., 2014).

Despite their diagnostic power, our understanding of the mode and efficacy of biomolecular signal transfer from source to sink remains rudimentary. In particular, we presently have limited knowledge of biomarker dynamics within river networks. While there is a growing number of studies of biomolecular loadings in continental margin sediments (e.g. Goni et al., 2013; Bröder et al., 2016a, 2016b; Tesi et al., 2016), corresponding investigations of riverine sediments are currently sparse (Goni et al., 2005; Tao et al., 2015), and have not focused on the longitudinal evolution of biomolecular signals along a river network. Moreover, the evolution of particle loadings of different biomolecular signals within river basins currently remains unexplored.

In this study, we have undertaken a detailed investigation of OM loadings on sediments within a major river system. In addition to TOC loadings, we determined loadings of biomarkers specific to soil (i.e., branched glycerol dialkyl glycerol tetraethers (brGDGTs)) and higher plants (i.e., long-chain plant wax fatty acids (FAs) and lignin phenols) in a suite of Danube River sediments collected from the headwaters to the delta. The observed evolution of TOC and biomarker loadings within the Danube River is discussed in the context of signals ultimately exported to the Black Sea, and more broadly in defining benchmark ranges for biomolecular loadings on river particles.

\section{STUDY AREA}

With a length of $2850 \mathrm{~km}$ and a catchment area of $801,500 \mathrm{~km}^{2}$, the Danube River (Fig. 1) is the largest river 


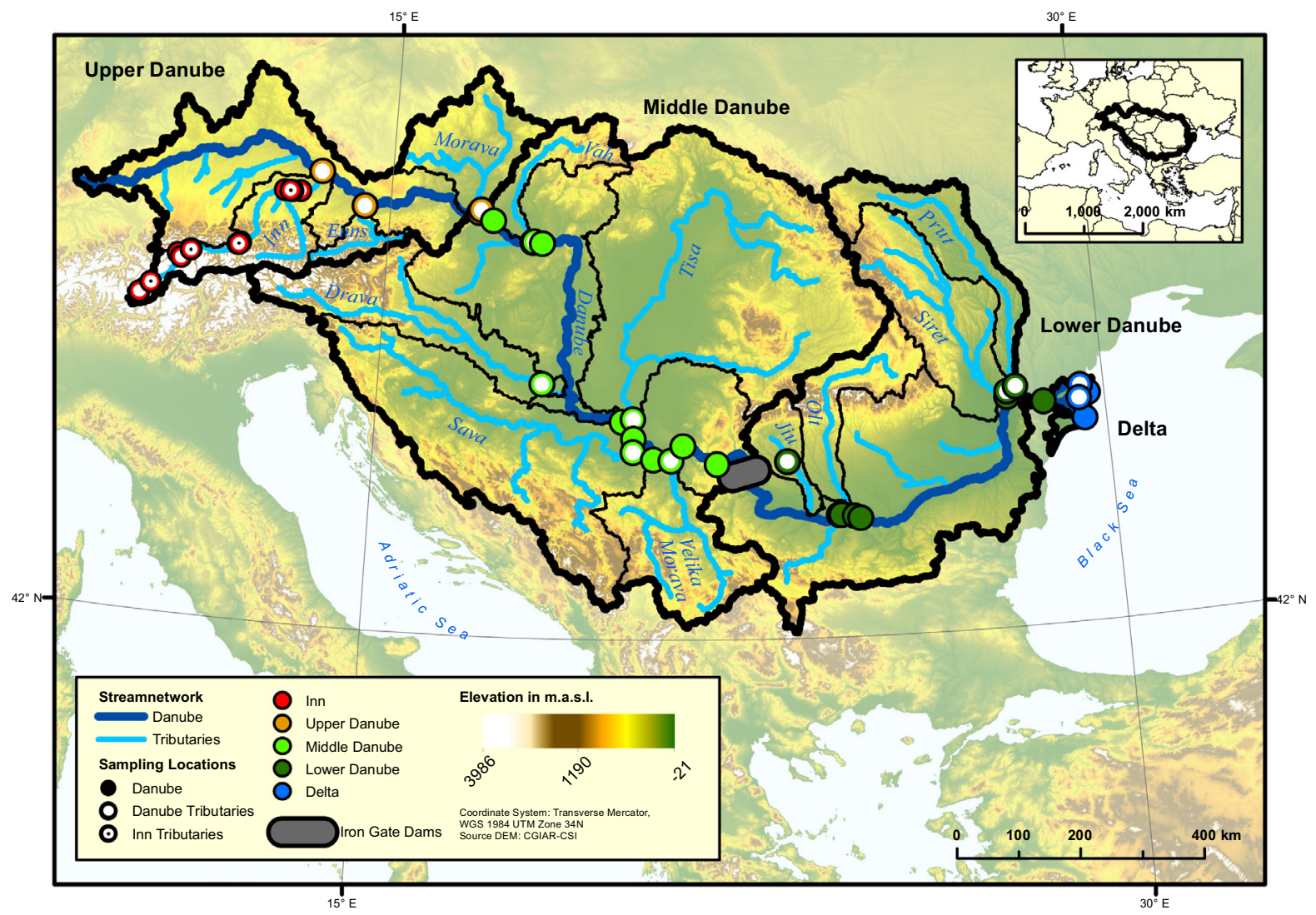

Fig. 1. The Danube River basin. Thick black lines show the catchment outline as well as the division into upper, middle, lower basin and delta region. Thin black lines are major tributary catchments. The Danube mainstream is shown in dark blue, tributaries in light blue. Sampling locations with a closed symbol correspond to Danube mainstem locations, open symbols to tributary locations. Sampling location colors correspond to sub-basins (orange: upper basin, light green: middle basin, dark green: lower basin, blue: delta). The Inn River, a tributary to the Danube in the upper basin, is shown with open, red symbols, tributaries to the Inn River are shown as open symbols with a black dot. (For interpretation of the references to color in this figure legend, the reader is referred to the web version of this article.)

of the European Union. The Danube is sourced from the Black Forest in southern Germany at an elevation of about $1000 \mathrm{~m}$ a.s.l and drains into the Black Sea with an average discharge of $6500 \mathrm{~m}^{3} / \mathrm{s}$ (ICPDR, 2005). The Danube catchment is typically divided into four sub-basins: (1) the upper basin from the source to the Gate of Devin downstream of Vienna at the confluence with the Morava River, where the foothills of the Eastern Alps and the Small Carpathians meet (ICPDR, 2005); (2) the middle basin from the Gate of Devin to the Iron Gate reservoir, where the Danube cuts the Carpathian mountains; (3) the lower basin from the Iron Gates to the beginning of the delta and (4) the delta region where the Danube mainstream splits into three main arms, forming a large wetland area $(675,000$ ha; ICPDR, 2005).

The Danube primarily drains the Mesozoic Alpine ranges outcropping crystalline rocks, limestones, flysch and molasse (e.g., Alps, Carpathians, Dinarics and Balkans together with their foothills) and intermountain plains such as the Pannonian and Romanian plains (e.g., Schiller et al., 2010). In addition, mostly crystalline Paleozoic plateaus are located in the upper basin (e.g., Schwarzwald Massif, Bohemian-Moravian Upland) and near the mouth (i.e., Dobrogea). The south-western part of the pre-Paleozoic
Russian Platform is drained by Danube tributaries crossing the Moldavian Plateau. Easily erodible loess covers most of the intermountain plains and plateaus especially in the mid and lower parts of the basin (Haase et al., 2007).

Mountainous soils in the Danube basin developed on crystalline or Mesozoic limestone bedrock. In high mountainous regions, rock-derived syrozems and leptosols with little humus predominate (Schiller et al., 2010). Below these high altitudes, cambisols and podzol-cambisols occur due to higher temperatures and denser vegetation cover. In low altitudes, deeper soils evolved on loose, Cenozoic sediment and alluvium fills. In river valleys and plains, floodplain soils developed, whereas cambisols, podzolcambisols and podzols characterize non-flooded areas, and luvisols formed on loess. Chernozems predominate in the plains of the lower Danube basin (Schiller et al., 2010).

\section{METHODS}

\subsection{Sample collection}

Detailed sampling of river sediment within the Danube River basin was performed in May and June 2013 and 2014, shortly after the yearly peak in discharge. In 2014, 
the sampling campaign was extended to include sediment sampling of the Inn River, the largest tributary to the Danube in the upper basin, discharging about $65 \%$ more water than the Danube at the confluence. In this study, the term "river sediment" is used for fine-grained sediment $(<1 \mathrm{~mm}$ grain size) that was recently deposited on the riverbanks or in hydrological quiescent locations in shallow water during decreasing water level of the previous high water event. Coarser and heavy minerals are preferentially deposited during sediment settling (e.g. Garzanti et al., 2009) and therefore, the deposited river sediment mineralogy is likely enhanced in coarse and heavy components compared to the overall suspended load. However, the coarser, denser and lower surface area riverbank sediment also exhibit lower OC concentration compared to actual sampling of suspended sediment (Fig. A1), most likely resulting in overall comparable OC loadings in suspended- and bank sediments when normalized to surface area. We therefore assume that bank sediment loadings are good representatives of the overall river sediment OC loadings.

Spanning a stretch of $\sim 2200 \mathrm{~km}, 20$ sites along the Danube mainstem and 12 tributaries were sampled between Passau (Germany) and the Black Sea. The sampling strategy included the collection of one freshly deposited river sediment sample at each of the 12 largest tributaries (Inn, Enns, Morava, Vah, Drava, Tisa, Sava, Velika Morava, Jiu, Olt, Siret, Prut) close to the confluence with the Danube as well as at the Danube mainstem both upstream and $5-10 \mathrm{~km}$ downstream of each major tributary confluence. In addition, nine sites along the Inn River and five smaller tributaries to the Inn were sampled in 2014. During the 2013 sampling campaign, a heavy rain event in the upper basin caused a 100-year flood in the upper and middle basin (Blöschl et al., 2013; Grams et al., 2014; ICPDR, 2014). Mostly sandy flood deposits rendered it impossible to find fine sediment at several planned locations in the upper and middle basin. Moreover, shortly before the second sampling campaign in 2014, another $>100$-year flood occurred, this time in the lower Sava catchment (ICPDR \& ISRBC, 2015). However, this latter event, while locally catastrophic, did not interfere with the sampling. At each sampling location where freshly deposited fine sediment was abundant, ca. $2 \mathrm{~kg}$ sediment was collected with a shovel and stored in zip lock bags at $-20{ }^{\circ} \mathrm{C}$ until further treatment.

\subsection{Sample treatment, extraction, measurements}

\subsubsection{Samples}

For this study, the 32 sediment samples from the Danube sampling in 2013 were analyzed for SA, TOC, FA, lignin-derived phenols, brGDGTs and mineralogy. In addition, 30 samples from the 2014 Danube field campaign were analyzed for SA and TOC, and a subset of samples from 2014 was analyzed for biomarkers (6 FA, 6 lignin phenols, 7 brGDGTs). The 14 Inn River samples were analyzed for SA, TOC, FA, lignin phenols, and brGDGTs (see Appendix B).

\subsubsection{Sieving}

Bulk river sediments were wet sieved with MilliQ water over $200 \mu \mathrm{m}$ and $63 \mu \mathrm{m}$ sieves on a shaking table in order to remove coarse particles and organic debris. The resulting $<63 \mu \mathrm{m}$ fraction was freeze-dried and kept frozen until further work-up.

\subsubsection{Sedimentological parameters}

For SA and grain size (GS) measurements, OM in the sediment fine fraction $(<63 \mu \mathrm{m})$ was removed by combustion $\left(12 \mathrm{~h}, 450{ }^{\circ} \mathrm{C}\right.$, cool down $\left.40^{\circ} \mathrm{C} / \mathrm{h}\right)$. Before SA measurement, samples were degassed under vacuum $\left(>2 \mathrm{~h}, 350{ }^{\circ} \mathrm{C}\right)$ to remove any remaining water. SA was measured with $\mathrm{N}_{2}$ using the BET method with a 5-point adsorption isotherm $\left(\mathrm{p} / \mathrm{p}_{0}=0.05-0.3\right)$ on a NOVA 4000 surface area analyzer (Keil et al., 1997). For GS distribution measurement, the sediment was dispersed in sodium polyphosphate $(1 \mathrm{~g} / \mathrm{L})$ overnight and subsequently measured under ultrasonication on a Malvern Mastersizer 2000.

\subsubsection{Sediment mineralogy}

For XRD measurements, $1 \mathrm{~g}$ of the $<63 \mu \mathrm{m}$ fraction of Danube 2013 sediments was wet-milled in ethanol to $<20 \mu \mathrm{m}$ using a McCrone Micronising mill. The resulting $<20 \mu \mathrm{m}$ fraction was dried overnight $\left(60^{\circ} \mathrm{C}\right)$ and further powdered and homogenized using a mini mill (Pulverisette 23). Randomly oriented powdered specimens and textured specimens were subsequently prepared. For randomly oriented powder specimens, the powdered material was introduced into a sample holder for packing and forming a flat surface using a razor blade, which minimizes preferential orientation (Zhang et al., 2003). Textured specimens show enhanced intensity of the basal reflexes of phyllosilicates thereby facilitating their identification following changes in the reflex positions in the XRD pattern after different treatments. The textured specimens were measured in air dry state, after ethylene glycol saturation (stored in ethylene glycol atmosphere at $60^{\circ} \mathrm{C}$ for $15 \mathrm{~h}$; for smectite identification) and after combustion $\left(550{ }^{\circ} \mathrm{C}, 2 \mathrm{~h}\right.$; for kaolinite identification). On a subset of five samples, textured specimens were additionally treated with formamide (measured after $30 \mathrm{~min}$ and after $3 \mathrm{~h}$; to distinguish halloysite, kaolinite and chlorite), and with guanidine carbonate (saturated solution; identification of vermiculite). XRD measurements were performed on a Bruker AXS D8 Theta-Theta diffractometer with a SolX detector using Co $\mathrm{K} \alpha$ radiation. The irradiated sample length was holding constant at $18 \mathrm{~mm}$ using an automatic $\theta$-compensating divergence slit. Powdered specimens were measured from 2 to $80^{\circ} 2 \theta$ with a step size of $0.02^{\circ}$ for $4 \mathrm{~s} / \mathrm{step}$ counting time. Textured specimens were measured from 2 to $30^{\circ} 2 \theta$ with step size of $0.02^{\circ}$ for $5 \mathrm{~s} / \mathrm{step}$. The qualitative phase composition was determined with the software DIFFRACplus (BRUKER AXS). On the basis of the peak position and their relative intensity, the mineral phases were identified in comparison to the PDF-2 database (International Centre for Diffraction Data). Quantification of minerals was achieved with BGMN/AutoQuan software using Rietveld refinement (Bergmann and Kleeberg, 1998). 


\subsubsection{TOC and bulk ${ }^{14} \mathrm{C}$ measurements}

Aliquots of the $<63 \mu \mathrm{m}$ sediment fractions were placed in $\mathrm{Ag}$ boats and de-carbonated in a desiccator under $\mathrm{HCl}$ vapor $\left(60^{\circ} \mathrm{C}, 3 \mathrm{~d}\right)$, followed by neutralization with $\mathrm{NaOH}$ $\left(60^{\circ} \mathrm{C} 3 \mathrm{~d}\right)$ (Hedges and Stern, 1984; Komada et al., 2008). The samples together with the silver boats were wrapped in tin boats and TOC was measured on a Vario MICRO cube elemental analyzer (Elementar Analysensysteme $\mathrm{GmbH}$ ).

For ${ }^{14} \mathrm{C}$ measurement of the 2013 apex sample, the resulting $\mathrm{CO}_{2}$ from the EA combustion was collected, graphitized with an Automated Graphitisation Equipment system (AGE; Nemec et al., 2010; Wacker et al., 2010) and the ${ }^{14} \mathrm{C}$ contents of the graphite was measured on a Mini radioCarbon Dating System (MICADAS; Synal et al., 2007; Christl et al., 2013). ${ }^{14} \mathrm{C}$ of de-carbonated 2014 sample was measured with an on-line EA-IRMSAMS system (McIntyre et al., 2016). TOC and bulk ${ }^{14} \mathrm{C}$ were measured at the Laboratory for Ion Beam Physics at ETH Zürich.

\subsubsection{Lipid analysis}

$30-50 \mathrm{~g}$ of each dry fine-grained $(<63 \mu \mathrm{m})$ river sediment sample was microwave extracted with dichloromethane/ methanol (DCM/MeOH 9:1 v:v, $25 \mathrm{~min}$ at $\left.100{ }^{\circ} \mathrm{C}\right)$. The resulting total lipid extract was saponified with $\mathrm{KOH}$ in $\mathrm{MeOH}\left(0.5 \mathrm{M}, 2 \mathrm{~h}\right.$ at $\left.70{ }^{\circ} \mathrm{C}\right)$. After the addition of $5 \mathrm{ml}$ MilliQ water with $\mathrm{NaCl}$, a neutral phase was obtained by liquid/liquid extraction with hexane (Hex). An acid fraction was then obtained from the aqueous phase after acidification to $\mathrm{pH} 2$ with $\mathrm{HCl}$ by liquid/liquid extraction with Hex:DCM (4:1 v:v).

Fatty acids ( $F A)$ : The fatty acids (in the acid fraction) were converted to fatty acid methyl esters (FAMEs) with $\mathrm{MeOH}: \mathrm{HCl}\left(95: 5 \mathrm{v}: \mathrm{v}, 12-18 \mathrm{~h}\right.$, at $\left.70^{\circ} \mathrm{C}\right)$. The FAME fraction was purified in two steps. First over a $\mathrm{SiO}_{2}$ column with $\mathrm{NaSO}_{4}$, eluting with (1) Hex, (2) DCM:Hex (2:1 v:v) and (3) DCM. The resulting fraction (2), containing the FAMEs, was passed over an $\mathrm{AgNO}_{3}-\mathrm{SiO}_{2}$ column using (1) DCM and (2) ethyl acetate to remove unsaturated FAMEs. FAMEs were measured on a gas chromatograph with a flame ionization detector (GC-FID; Agilent Technologies 7890A) equipped with an Agilent VF-1 ms column (30 $\mathrm{m} \times 250 \mu \mathrm{m}$ ID $\times 0.25 \mu \mathrm{m}$ film thickness). The temperature program started with a $1 \mathrm{~min}$ hold time at $50{ }^{\circ} \mathrm{C}$, followed by a $10^{\circ} \mathrm{C} / \mathrm{min}$ ramp to $320^{\circ} \mathrm{C}$ and a 5 min hold time $320^{\circ} \mathrm{C}$. FAMEs were quantified against an external FAME standard (Supelco, $n$ - $\mathrm{C}_{4-24}$ even carbon saturated FAMEs) and are reported as long chain FA concentrations (sum $n$ $\mathrm{C}_{24-32}$, even $\mathrm{C}$ numbers).

brGDGTs: The preparation of a brGDGT fraction from the neutral phase and its subsequent measurement is described in Freymond et al. (2017). The brGDGT concentration data reported here were acquired with the 'classic' method, i.e. without the separation of 5-methyl and 6methyl brGDGT isomers, using an HPLC-APCI-MS equipped with a Grace Prevail cyano column $(150 \mathrm{~mm} \times$ $2.1 \mathrm{~mm}, 3 \mu \mathrm{m}$ ) (Schouten et al., 2007; Freymond et al., 2017). This form of data is presented so that all available Danube catchment data, including samples that were not measured with the 'improved chromatography' method, could be used. As shown in Freymond et al. (2017), brGDGT concentrations measured with the two methods correlate strongly $\left(\mathrm{r}^{2}=0.95, \mathrm{p}\right.$-value $\left.<0.05\right)$, although the 'classic' method gives on average 34\% higher values than the 'improved chromatography' method. For proxy calculation see Freymond et al. (2017).

\subsubsection{Lignin analysis}

Lignin phenols were released by microwave-assisted alkaline $\mathrm{CuO}$ oxidation (Goni and Montgomery, 2000). In short, about $100 \mathrm{mg}$ cupric oxide, $50 \mathrm{mg}$ ferrous ammonium sulfate, and $100 \mathrm{mg}$ of pre-solvent-extracted finegrained $(<63 \mu \mathrm{m})$ sediment sample were combined in ca. $30 \mathrm{ml} 2 \mathrm{~N} \mathrm{NaOH}$ solution (deoxygenated with $\mathrm{N}_{2}$ gas for a minimum of five minutes) in Teflon microwave tubes and the vessels were sealed with a $\mathrm{N}_{2}$ headspace. The microwave system was run with a $30-\mathrm{min}$ ramp time and $90 \mathrm{~min}$ holding at $150{ }^{\circ} \mathrm{C}$. After oxidation, the alkaline solution was siphoned off and the residue rinsed at least three times with $\mathrm{NaOH}$, or until the solution was clear. Then, $10 \mu \mathrm{L}$ of internal standard (ethylvanillin, trans-cinnamic acid, $1 \mu \mathrm{g} / \mu \mathrm{L}$ ) was added to each sample. The samples were acidified to $\mathrm{pH} 2$ using $37 \% \mathrm{HCl}$. Following addition of MilliQ water with $\mathrm{NaCl}$, the phenols were extracted three times with ethyl acetate. To remove water, $\mathrm{NaSO}_{4}$ was added to the vials until it did not clump. The extracts (in ethyl acetate) were dried under a stream of $\mathrm{N}_{2}$ and subsequently derivatized with $50 \mu \mathrm{L}$ of BSTFA and $50 \mu \mathrm{L}$ pyridine $\left(70^{\circ} \mathrm{C}, 30 \mathrm{~min}\right.$.)

Lignin phenols were separated and quantified on a GC-FID (Agilent Technologies 7890A) equipped with an Agilent HP-1 ms column $(60 \mathrm{~m} \times 250 \mu \mathrm{m}$ ID $\times 0.25 \mu \mathrm{m}$ film thickness). The temperature program was set as follows: after an initial hold time of $1.5 \mathrm{~min}$ at $70^{\circ} \mathrm{C}$, temperature was ramped at $30^{\circ} \mathrm{C} / \mathrm{min}$ to $115^{\circ} \mathrm{C}$, followed by a $3{ }^{\circ} \mathrm{C} / \mathrm{min}$ ramp to $230^{\circ} \mathrm{C}$, a $40{ }^{\circ} \mathrm{C} / \mathrm{min}$ ramp to $320^{\circ} \mathrm{C}$ and a $10 \mathrm{~min}$ hold time at $320^{\circ} \mathrm{C}$. Lignin phenols were quantified against the two internal standards (ethylvanillin to quantify vanillin and syringaldehyde; trans-cinnamic acid to quantify acetovanillone, vanillic acid, acetosyringone, syringic acid, p-coumaric acid, ferulic acid). Concentrations reported in this study correspond to the sum of the eight lignin phenols (acetovanillone, syringaldehyde, vanillic acid, acetosyringone, syringic acid, p-coumaric acid, ferulic acid).

\subsubsection{Data analysis}

The statistic program R (R Core Team, 2014) was used for data analysis and visualization. Relationships between different parameters were assessed by linear regression models where p-values $<0.05$ were considered to be significant.

\section{RESULTS}

\subsection{Sediment fine-fraction characteristics}

Mineral SA values along the Inn and Danube mainstream (Fig. 2a) show a linear trend of increasing values, starting from $\sim 3 \mathrm{~m}^{2} / \mathrm{g}$ in the upper Inn River basin to 
$30 \mathrm{~m}^{2} / \mathrm{g}$ at the apex of the delta, followed by somewhat lower values within the delta region (delta average: $17 \mathrm{~m}^{2} / \mathrm{g}$ ). Tributaries follow this trend of increasing values from $2 \mathrm{~m}^{2} / \mathrm{g}$ (Inn River tributary in upper Danube basin) to $48 \mathrm{~m}^{2} / \mathrm{g}$ (Vedea River in the lower Danube basin) with often slightly higher values than the mainstem, and therefore contribute to the increase in SA in Danube sediments. Median GS (Fig. 2b) varies from about $6 \mu \mathrm{m}$ to $25 \mu \mathrm{m}$ and shows an evolution inverse to SA. Linear regression between SA and GS yields an $r^{2}=0.6$ (p-value $<0.05$ ).

Illite and smectite are the phyllosilicates with the largest SA identified in the Danube sediments (BET SA of illite: $20 \mathrm{~m}^{2} / \mathrm{g}\left(\mathrm{N}_{2}\right.$-BET measurement, Dogan et al., 2007) and smectite: $50-130 \mathrm{~m}^{2} / \mathrm{g}\left(\mathrm{N}_{2}\right.$-BET measurement, Kaufhold et al., 2010)). The swelling capacity of smectite further increases the available mineral surface area in the interlayer space. The sum of these two minerals (Fig. A2) increases in the mainstem sediments from $13 \mathrm{wt} \%$ of total sediment fine fraction in the upper Danube basin to $25 \mathrm{wt} \%$ at the beginning of the Iron Gate Reservoir, and $30 \mathrm{wt} \%$ downstream of the reservoir, followed by a decrease to $15 \mathrm{wt} \%$ at the mouth of the river. Illite + smectite content of the tributaries follow this evolution, and range from $6 \mathrm{wt} \%$ to 33 $\mathrm{wt} \%$. Due to their similar evolution along the river, illite + smectite content exhibits a significant correlation with sediment SA $\left(r^{2}=0.62\right.$, p-value $<0.05$; Figs. A2 and $\left.2 \mathrm{a}\right)$. Kaolinite content shows a similar evolution along the
Danube to that of illite + smectite, with increasing values from the upper basin to the beginning of the lower basin, followed by a decrease towards the delta. However, the kaolinite content is lower than illite and smectite, ranging from 0 to $8 \%$ (Appendix B). On a weight basis, the adsorption capacity of phyllosilicates increases in the order of kaolinite $<$ illite $<$ smectite (Saidy et al., 2013; Nguyen and Marschner, 2016; Singh et al., 2016), especially in the pH range of Danube River water of about 8 (JDS3, 2013; Chotzen et al., 2016), rendering illite + smectite the main drivers in the sorption of OC in Danube sediments. Quantitative data for all minerals are listed in Appendix B.

The most common sediment pretreatment for SA measurements in environmental and geological studies involves the removal of OM either by wet chemical oxidation (e.g. Keil et al., 1994; Mayer, 1994; Ransom et al., 1998) or thermal treatment (e.g. Bao et al., 2016; Coppola et al., 2007; Wakeham et al., 2009). OM removal eliminates a low-density component from the sample, which exhibits a low nitrogen-based SA (mostly $<1 \mathrm{~m}^{2} / \mathrm{g}$, less frequently 1-20 m²/g; Chiou et al., 1990; Pennell et al., 1995). The removal of this component leads to a concentration of the mineral mass, which results in an increase or decrease in the mass-normalized mineral SA. Thermal treatment at low temperatures $\left(\leq 150^{\circ} \mathrm{C}\right)$ results in a decrease in mineral SA (Kaufhold et al., 2010; Valter and Plötze, 2013). Generally, this loss of mineral SA is observed for various

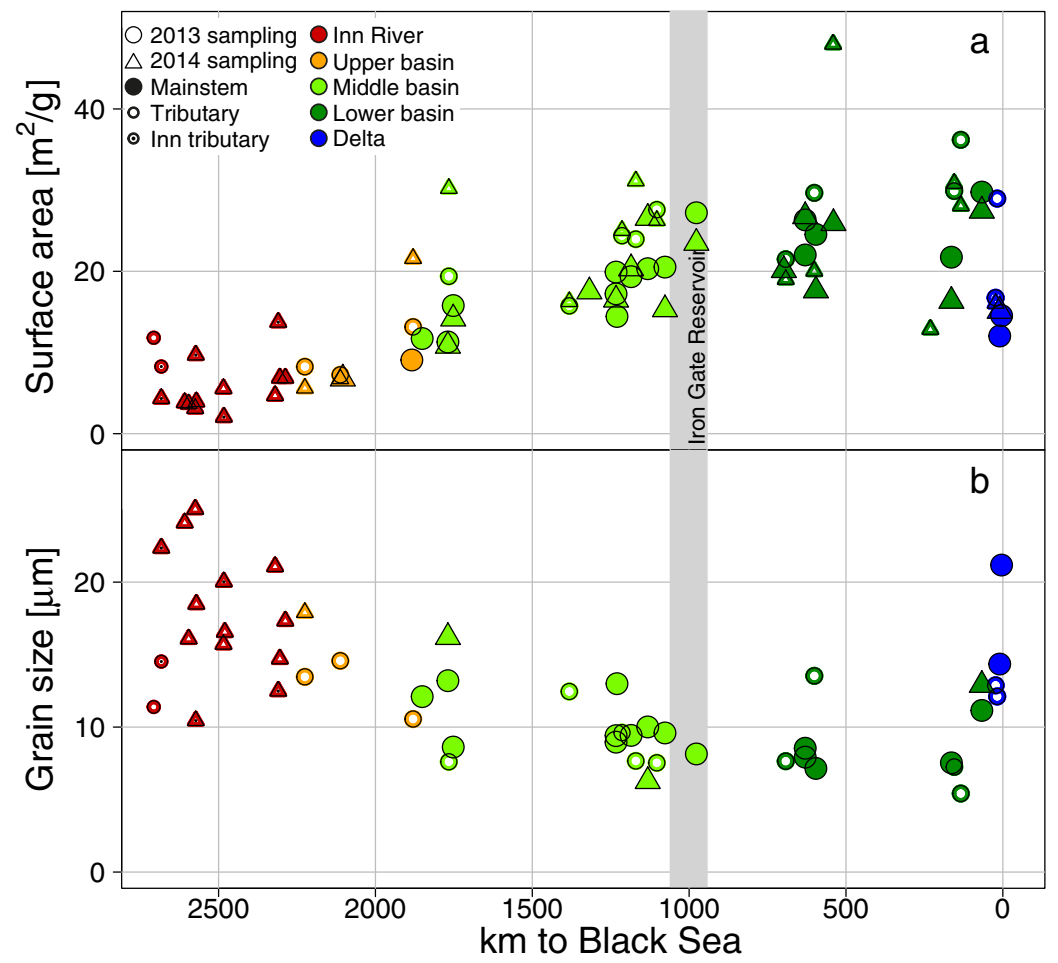

Fig. 2. (a) Mineral surface area and (b) median grain size along the river. Symbol colors correspond to sub-basins (red: Inn River in the upper basin; orange: upper Danube basin; light green: middle Danube basin; dark green: lower Danube basin; blue: delta region). Circles show samples from 2013, triangles from 2014. Closed symbols correspond to Danube mainstem locations, open symbols to tributary locations. Open red triangles are locations at the Inn mainstem, Inn tributary locations are shown as open symbols with a black dot. The gray bar indicates the location of the Iron Gate reservoir. (For interpretation of the references to color in this figure legend, the reader is referred to the web version of this article.) 
phyllosilicates over a continuous range of temperatures $\left(<600{ }^{\circ} \mathrm{C}\right.$; e.g. Noyan et al., 2006; Plesingerova et al., 2011). Most studies reporting thermally-treated mineral SA data have heated sediment samples at $350^{\circ} \mathrm{C}$. A concern is the efficacy of $\mathrm{OM}$ removal at $350{ }^{\circ} \mathrm{C}$ due to the formation of charred residues (Masiello, 2004; Wakeham et al., 2009) and thermally recalcitrant OM components (i.e. petrogenic carbon; Hemingway et al., 2017). Chars may exhibit variable and potentially high SA $\left(>50 \mathrm{~m}^{2} / \mathrm{g}\right.$; e.g. Downie et al., 2009) and lead to an overestimate of the mineral SA (Wakeham et al., 2009). The lithogenic nature of the fluvial sediment samples at hand warranted a higher temperature treatment $\left(450{ }^{\circ} \mathrm{C}\right)$ to ameliorate this effect. While results from the present study are internally consistent, caution should be exercised in comparison of SA across studies that have employed different methods and investigated different matrices.

\subsection{TOC, fatty acid, brGDGT and lignin concentrations}

TOC values of Inn and Danube mainstem sediments (Fig. 3a) increase from $0.25 \%$ in the Inn basin to $2.04 \%$ in the Iron Gate reservoir and show a decrease after the dam to $0.50 \%$ at the mouth. Tributaries follow the same trend and range between $0.40 \%$ and $2.30 \%$.

Long-chain FA ( $\left.n-\mathrm{C}_{24-32}\right)$, as well as brGDGT and lignin concentrations (Figs. 4a, 5a and 6a) correlate with TOC (Fig. 3a) $\left(r^{2}=0.54 ; 0.46\right.$ and 0.51 , respectively; p-values $<0.05$ ), and show similar evolution patterns along the Danube to that of TOC with low values along the Inn River, concentration maxima upstream of the Iron Gate dam and decreasing values towards the Black Sea (Figs. 3a, 4a, 5a and 6a). Long-chain FA ( $n-\mathrm{C}_{24-32}$ concentrations range from 1.8 to $30.1 \mu \mathrm{g} / \mathrm{g}_{\mathrm{dw}}$ (Fig. 4a), brGDGT concentrations from 0.03 to $3.09 \mu \mathrm{g} / \mathrm{g}_{\mathrm{dw}}$ (Fig. 5a) and lignin concentrations from 1.7 to $283.9 \mu \mathrm{g} / \mathrm{g}_{\mathrm{dw}}$ (Fig. 6a).

FA concentrations normalized to TOC content (Fig. 4b) range between 0.40 and $2.55 \mathrm{mg} / \mathrm{g}_{\mathrm{OC}}$, showing relatively constant values along the Inn and Danube (average, $\left.0.96 \pm 0.40 \mathrm{mg} / \mathrm{g}_{\mathrm{OC}}\right)$. BrGDGT concentrations normalized to TOC (Fig. 5b) increase along the Inn River from 7.7 to $29.1 \mu \mathrm{g} / \mathrm{g}_{\mathrm{OC}}$ and remain at roughly constant levels along the Danube mainstem, though differing between sampling campaigns (2013 average, $51.8 \pm 16.6 \mu \mathrm{g} / \mathrm{g}_{\mathrm{OC}} ; 2014$ average, $\left.103.3 \pm 35.5 \mu \mathrm{g} / \mathrm{g}_{\mathrm{OC}}\right)$. In contrast to FAs and brGDGTs, lignin concentrations normalized to TOC (Fig. 6b) show an increase from $0.48 \mathrm{mg} / \mathrm{g}_{\mathrm{OC}}$ at the Inn River headwaters to $15.3 \mathrm{mg} / \mathrm{g}_{\mathrm{OC}}$ upstream of the Iron Gates Reservoir, followed by decreasing values after the dams.

Normalizing TOC to SA (Fig. 3b) reveals a linear decrease $\left(r^{2}=0.76, \mathrm{p}\right.$-value $\left.<0.05\right)$ in loadings along the Danube mainstem locations from the upper basin $\left(1.48 \mathrm{mg}\right.$ oC $\left./ \mathrm{m}^{2}\right)$ to the lower basin $\left(0.26 \mathrm{mg}\right.$ oC $\left./ \mathrm{m}^{2}\right)$. From the uppermost mainstem location in the upper basin to the most downstream location in the lower basin before

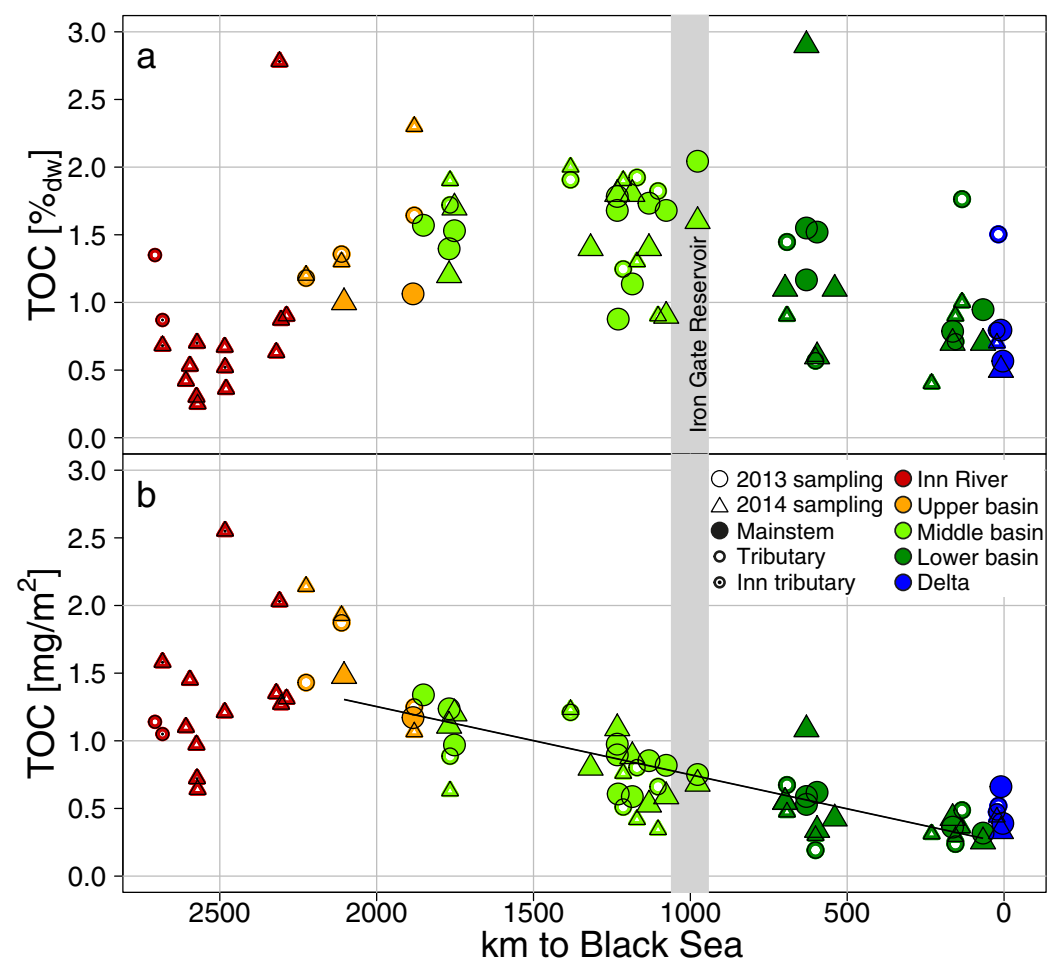

Fig. 3. Evolution of TOC content along the river. (a) TOC $\left(\% \mathrm{dw}_{\mathrm{dw}}\right)$, (b) TOC normalized to $\mathrm{SA}\left(\mathrm{mg} \mathrm{OC} / \mathrm{m}^{2}\right)$ as a function of distance to the Black Sea $(2500 \mathrm{~km}$ alpine tributary; $0 \mathrm{~km}$ river mouth(s) at the Black Sea). The regression line in panel b) corresponds to data from Danube mainstem sampling locations only (closed symbols). Symbol color and shape correspond to sampling locations in Figs. 1 and 2 . The vertical gray bar indicates the location of the Iron Gate reservoir. (For interpretation of the references to color in this figure legend, the reader is referred to the web version of this article.) 


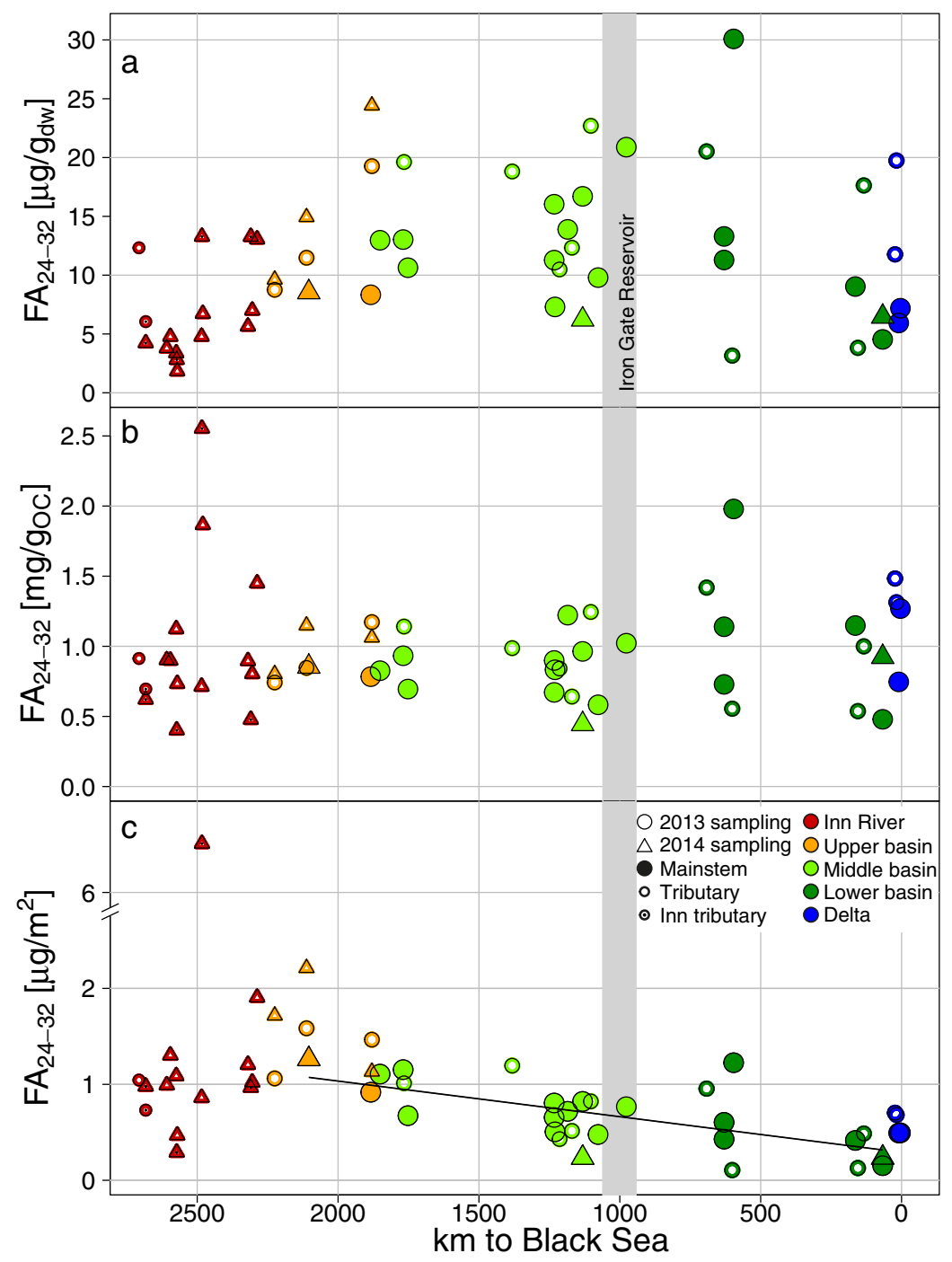

Fig. 4. Evolution of long-chain $\left(n-\mathrm{C}_{24-32}\right)$ FAs along the river. (a) FA concentrations normalized to sediment weight ( $\left.\mu \mathrm{g} / \mathrm{g}_{\mathrm{dw}}\right)$, (b) FA concentrations normalized to TOC ( $\left.\mathrm{mg} / \mathrm{g}_{\mathrm{OC}}\right)$, (c) FA concentrations normalized to mineral-specific SA in $\mu \mathrm{g}_{\mathrm{FA}} / \mathrm{m}^{2}$ at distance to the Black Sea. The regression line in panel (c) corresponds to Danube mainstem sampling locations only. Symbol color and shape correspond to sampling locations in Figs. 1 and 2. (For interpretation of the references to color in this figure legend, the reader is referred to the web version of this article.)

the delta, TOC loadings decrease by $79 \%$, corresponding to a loss of $50 \mu \mathrm{g}_{\mathrm{OC}} / \mathrm{m}^{2}$ per $100 \mathrm{~km}$. Loadings along the Inn River range between 0.64 and $2.55 \mathrm{mg}$ oc $/ \mathrm{m}^{2}$ (average $1.32 \pm 0.48 \mathrm{mgoC} / \mathrm{m}^{2}$ ). Only considering the Inn mainstem, a weak and not significant trend $\left(r^{2}=0.26, \mathrm{p}\right.$-value $\left.=0.13\right)$ of increasing OC loadings from the headwaters to the confluence of the Inn with the Danube is apparent.

FA (Fig. 4c), brGDGT (Fig. 5c) and lignin (Fig. 6c) loadings of Danube mainstem sediments also exhibit a general decrease with distance along the river, albeit with greater scatter $\left(r^{2}=0.46,0.38\right.$ and 0.51 , respectively; p-values $<0.05$ ). Calculated decreases from the uppermost mainstem location in the upper basin to the most downstream location in the lower basin are as follows: $70 \%$ for FAs (corresponding to $-36 \mathrm{ng}_{\mathrm{FA}} / \mathrm{m}^{2}$ per $100 \mathrm{~km}$ ); $81 \%$ for brGDGTs $\left(-3.1 \mathrm{ng}_{\mathrm{brGDGT}} / \mathrm{m}^{2}\right.$ per $\left.100 \mathrm{~km}\right) ; 82 \%$ for lignin $\left(-400 \mathrm{ng}_{\text {lignin }} / \mathrm{m}^{2}\right.$ per $\left.100 \mathrm{~km}\right)$. The Inn River shows a weak trend to increasing FA and lignin loadings whereas the brGDGT loadings increase linearly $\left(r^{2}=0.79\right.$, p-value $<0.05$, excluding the outlier at $\mathrm{km}=2707)$.

Cross-plotting TOC versus SA (Fig. 7a), river sediments from the Inn and Danube yield an average TOC/SA ratio of $0.86 \pm 0.49(\mathrm{stdv}) \mathrm{mg}_{\mathrm{oc}} / \mathrm{m}^{2}$, and mostly fall into the range considered typical for river suspended sediments $\left(0.4-1 \mathrm{mg}_{\mathrm{oC}} / \mathrm{m}^{2}\right.$; Blair and Aller, 2012). Locations in the upper basin generally exhibit higher TOC loadings and are located outside of this window. Moving downstream to the middle basin and further to the lower basin, the TOC/SA ratio decreases while absolute values for both TOC and SA increase, and most of the locations in the lower basin fall below $0.4 \mathrm{mg}$ oc $/ \mathrm{m}^{2}$. The delta locations exhibit relatively low absolute TOC and SA values, but fall 


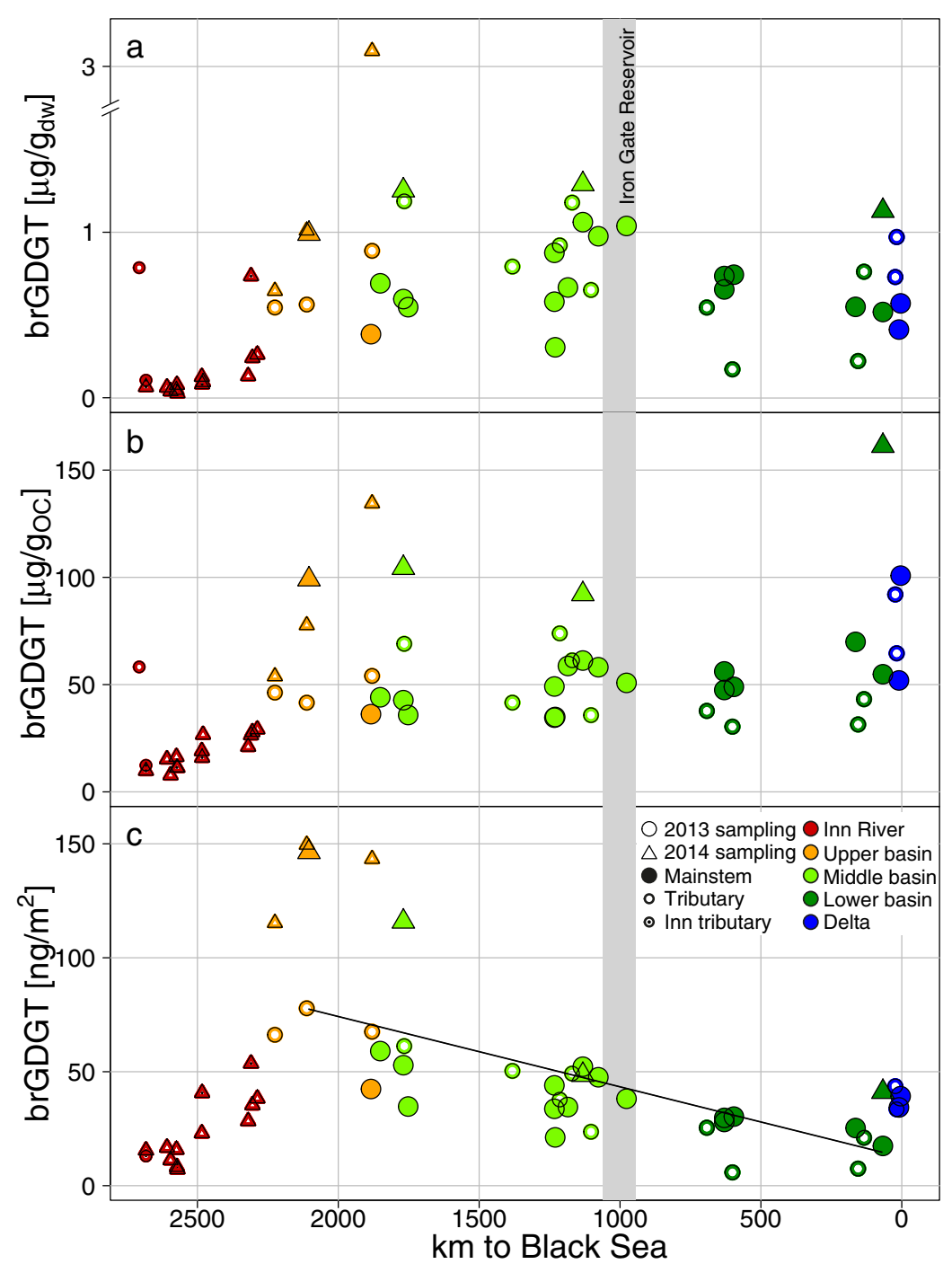

Fig. 5. Evolution of brGDGTs along the river. (a) BrGDGT concentrations normalized to sediment weight in $\mu \mathrm{g} / \mathrm{g}_{\mathrm{dw}}$, (b) brGDGT concentrations normalized to TOC in $\mu \mathrm{g} / \mathrm{g}_{\mathrm{OC}}$, (c) brGDGT concentrations normalized to SA in $\mathrm{ng} / \mathrm{m}^{2}$ at distance to the Black Sea. The regression line in panel (c) corresponds to Danube mainstem sampling locations only. Symbol color and shape correspond to those in Figs. 1 and 2. (For interpretation of the references to color in this figure legend, the reader is referred to the web version of this article.)

into the typical suspended sediment window. Thus, TOC/ SA values of river mainstem sediments appear to develop along an elliptical orbit (depicted in Fig. 7e), moving clockwise from close to the origin in headwater samples and returning to similar coordinates in the plot for delta samples (Fig. 7a). FA, brGDGT and lignin phenol concentrations when plotted against SA (Fig. 7b-d) show a similar pattern to that of TOC, albeit with greater scatter and slightly varying "orbits" (Fig. 7a-e).

\section{DISCUSSION}

\subsection{Concept of mineral surface area normalization}

OC and biomarker concentrations in fluvial and other sediments are typically normalized to sediment dry weight $(\mathrm{dw})$, however, this approach does not account for changes in mineral composition and hydrological sorting effects in aquatic systems (Blair and Aller, 2012). For biomarker concentrations, this issue can be at least partially obviated by normalizing to TOC content, however quantitative information is lost concerning how OC and specific biomarker concentrations vary as a function of the overall suspended sediment load. By normalizing OC and biomarker concentrations to mineral SA, OC and biomarker loadings are created, taking the mineral composition as well as hydrological sorting effects into account. Coarse particles with little SA and low OC and biomarker concentrations result in similar OC/SA ratios as fine particles with high SA and high OC and biomarker concentration. Keil et al. (1997) used SA as a quasi-conservative property in order to study OM loss and replacement on mineral surfaces of riverine particulate matter in estuarine and deltaic systems. With the assumption that $\mathrm{SA}$ is a conservative parameter and that most 


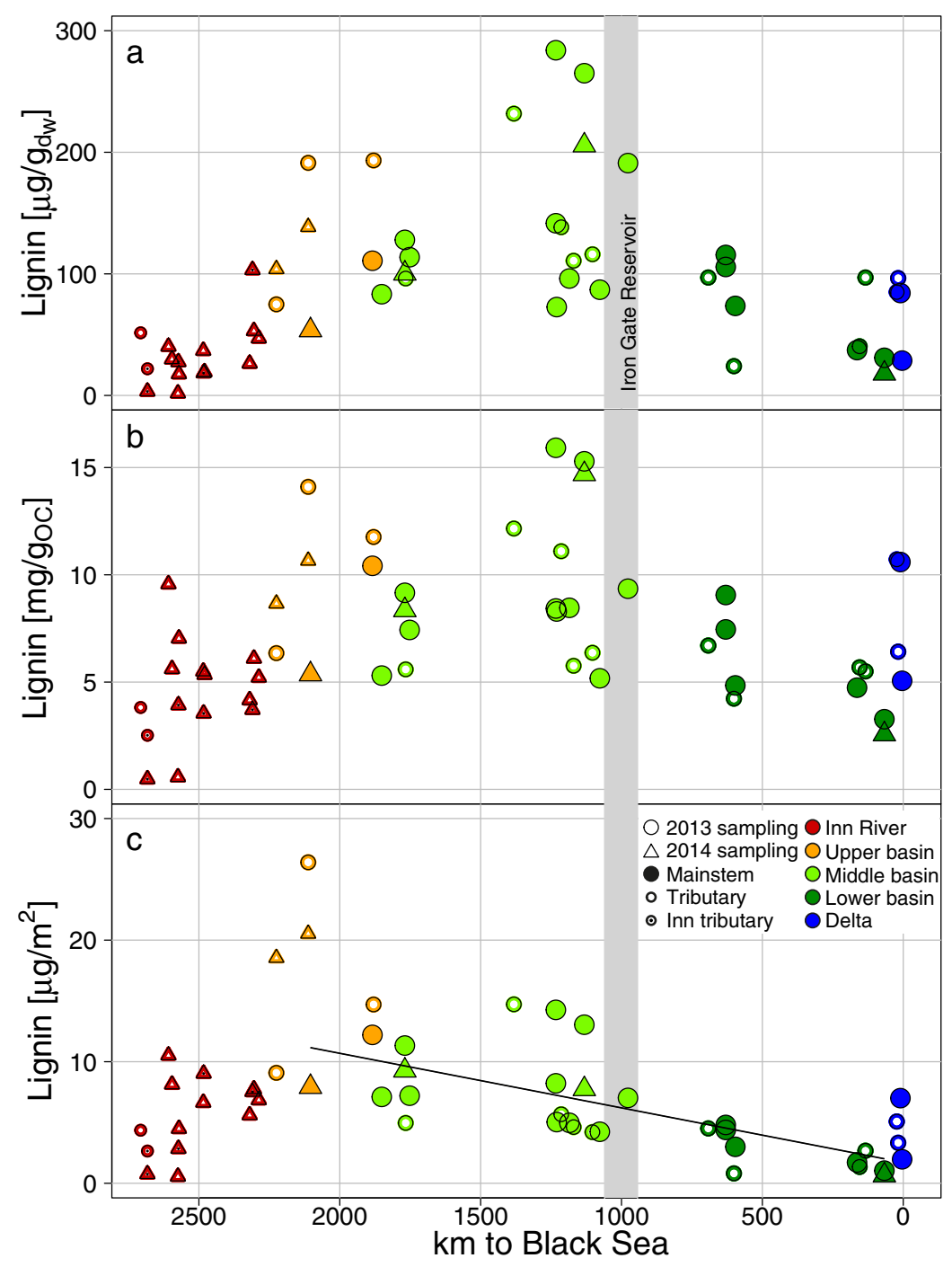

Fig. 6. Evolution of lignin along the river. (a) Lignin concentrations normalized to sediment weight in $\mu \mathrm{g} / \mathrm{g}_{\mathrm{dw}}$, (b) lignin concentrations normalized to TOC in $\mathrm{mg} / \mathrm{g}_{\mathrm{OC}}$, (c) lignin concentrations normalized to SA in $\mu \mathrm{g} / \mathrm{m}^{2}$ at distance to the Black Sea. The regression line in panel (c) corresponds to Danube mainstem sampling locations only. Symbol color and shape correspond to those in Figs. 1 and 2. (For interpretation of the references to color in this figure legend, the reader is referred to the web version of this article.)

particulate $\mathrm{OC}$ is associated with mineral surfaces, changes in TOC loading should reflect the net exchange of carbon on mineral surfaces (Keil et al., 1997). For this study, the river sediments were sieved to $<63 \mu \mathrm{m}$ with the goal of excluding any large plant debris (that may be derived from local riverbank erosion) and reducing grain size variations. Grain size variations within this clay/silt fraction do persist, as revealed by the gradual decrease in median GS towards the delta, together with a corresponding increase in SA (Fig. 2). Our basin-wide quantification of phyllosilicate contents (i.e., illite + smectite; Fig. A2) also shows an increase in the proportion of the high SA clay minerals illite + smectite relative to total sediment weight from the upper basin to the beginning of the lower basin. In general, mainstem sediments of a large river like the Danube River represent the sum of tributary inputs along the river, contributing to the sediment signal by adding mineralogical signals reflective of their respective catchments. Seen from the terminus of the river, the mineralogy of the exported river sediment and the corresponding SA represents an integrated signal of the evolving signal along the flow path (Martin and Meybeck, 1979). However, corresponding SA along a river potentially not only changes due to tributary inputs but could also be affected by different processes. The abrasion of coarse mineral grains during transport decreases with decreasing grain size. In large sand bed rivers, abrasion is generally small but might be more important in the uppermost parts of the catchment (Frings, 2008). Further, the formation of secondary phyllosilicates in temporary traps (e.g., bars and floodplains) would add new high SA particles to the sediment. This process is difficult to quantify, however, in case of the Danube, natural floodplains are scarce due to river regulation. In Danube tributaries sediments, both SA values (Fig. 2a) and 


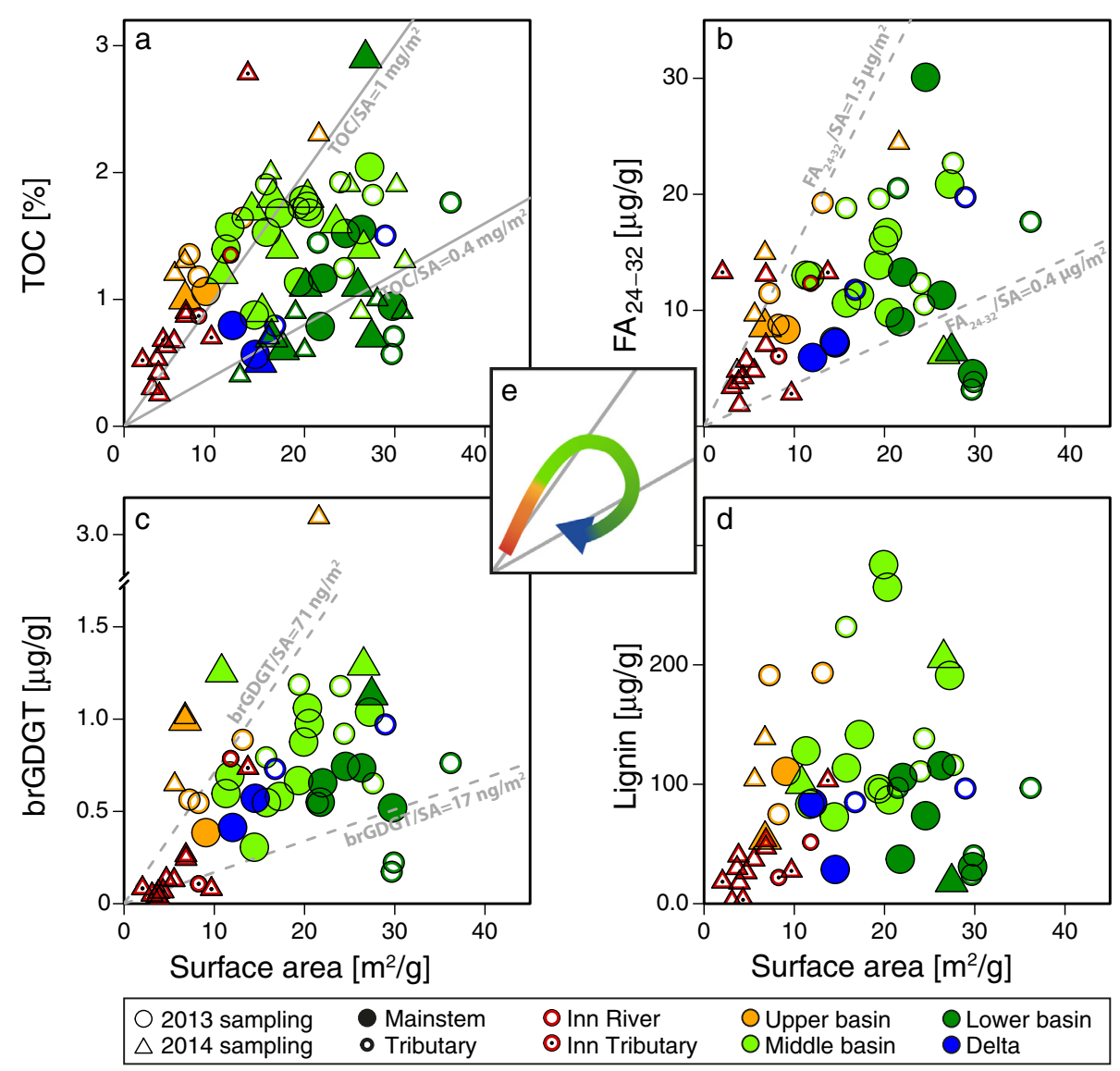

Fig. 7. (a) TOC, (b) FA, (c) brGDGT and (d) lignin concentrations against SA. Gray lines in (a) correspond to the typical river suspended sediment range of $0.4-1 \mathrm{mg}_{\mathrm{OC}} / \mathrm{m}^{2}$, defined by Blair and Aller (2012). Dashed gray lines in (b) and (c) correspond to proposed "typical" river sediment biomolecular loading ranges of $0.4-1.5 \mu \mathrm{g}_{\mathrm{FA}} / \mathrm{m}^{2}$ and $17-71 \mathrm{ng}_{\mathrm{brGDGT}} / \mathrm{m}^{2}$. (e) Schematic evolution of the loadings from the upper basin (red, orange) to the delta (blue). Symbol color and shape correspond to sampling locations in Figs. 1 and 2. (For interpretation of the references to color in this figure legend, the reader is referred to the web version of this article.)

phyllosilicate concentrations (Fig. A2) follow a similar increasing trend from the upper to the lower Danube basin and show a significant correlation $\left(r^{2}=0.62\right.$, p-value $<0.05)$. The increase in SA can mostly be explained by the increase in phyllosilicate content, suggesting that inputs from middle and lower basin tributaries are the main driver for the observed SA trend. Therefore, we suggest that SA serves as a useful property against which to assess potential variations in $\mathrm{OM}$ loading, and we argue that this property is likely to be more constant than others used for assessment of changes in OM concentrations.

\subsection{Biomolecular loadings on river sediments}

Blair and Aller (2012) adopted the concept of general ranges in SA normalized OC loadings of continental margin sediments that was first developed by Mayer (1994), and found a ratio of $0.4-1 \mathrm{mg} / \mathrm{m}^{2}$ to be representative of river-dominated continental margin sediments. We apply this concept to recent Danube River sediments, and find that they mostly plot within this "typical" river suspended sediment range, but follow a distinct pattern along the course of the river as described in the following, and also depicted in Fig. 7e. Sediments with higher OC/SA ratio (at the upper end of the window) - defined by Blair and Aller (2012) as freshly deposited with short oxygen exposure time - are located in the upper basin and at the beginning of the middle basin of the catchment. Moving downstream, OC/SA ratios decrease and corresponding sediments plot towards the lower end of the window. Some sediments, mostly from the lower basin, have lower OC/SA ratios than the typical river suspended sediment window (i.e., $<0.4 \mathrm{mg} / \mathrm{m}^{2}$ ), which according to Blair and Aller (2012) would imply that the associated OM has been subject to protracted oxygen exposure.

Here, we extend this same concept with respect to the concentration of three established groups of biomolecular tracer compounds: FAs, brGDGTs and lignin-derived phenols. We find a similar clustering as for TOC, and similar headwater-to-delta evolutionary trajectories (Fig. 7a-e). Based on these patterns, we propose windows reflecting "typical" river suspended sediment for FA and brGDGT loadings for the Danube River system (Fig. $7 \mathrm{~b}$ and c). The Danube TOC loading (TOC/SA) data is fitted by a log-normal distribution and the range of characteristic river loadings is defined as covering $68 \%$ around the mean of the 
fitted distribution $(1 \sigma)$. With this definition, Danube sediments are characterized by a TOC loading ranging from $0.4 \mathrm{mg}$ OC $/ \mathrm{m}^{2}$ to $1.3 \mathrm{mgoC} / \mathrm{m}^{2}$, close to TOC loadings of Blair and Aller (2012) $\left(0.4 \mathrm{mg} / \mathrm{m}^{2}\right.$ and $\left.1 \mathrm{mg} / \mathrm{m}^{2}\right)$. The somewhat higher upper value found for the Danube $\left(1.3 \mathrm{mg}\right.$ oC $\left./ \mathrm{m}^{2}\right)$ may reflect the fact that the sediments in the present study are actual river sediments and thus subject to less degradation than river-influenced continental margin sediments. Accordingly, windows for FAs and brGDGTs were defined similarly (dashed lines in Fig. $7 b$ and c). For long-chain $\left(n-\mathrm{C}_{24-32}\right)$ FAs, we therefore define $0.4-1.5 \mu \mathrm{g}_{\mathrm{FA}} / \mathrm{m}^{2}$ and for brGDGTs $17-71 \mathrm{ng}_{\mathrm{brGDGT}} / \mathrm{m}^{2}$ as ranges for Danube River biomarker loadings (Fig. $7 \mathrm{~b}$ and c). Lignin-derived phenols display less systematic behavior, as indicated by greater scatter when concentrations are plotted with respect to SA (Fig. 7d). We attribute this to the presence of lignin both as discrete (woody) debris and associated with mineral surfaces. Additionally, lignin as a structural polymer is present in the particulate as well as in the dissolved phase due to the weaker hydrophobicity than for example fatty acids or other long alkyl chain lipids, potentially further weakening the correlation between lignin and mineral surface area. The higher TOC- and SA-normalized lignin concentrations in the middle basin compared to the other biomarkers (Fig. 6b and c) is consistent with enhanced deposition of litter/debris due to slower water velocity upstream of the Iron Gate dam.

\subsection{Evolution of organic carbon loadings within the river basin}

In the Inn tributary and Danube mainstem, organic carbon, as well as biomarker loadings evolve in a distinct pattern from the headwaters towards the Black Sea, which is further discussed below (Figs. 3b, 4c, 5c and 6c).

From the alpine source in the upper basin (2484 $\mathrm{m}$ a.s.l) to the confluence with the Danube ( $\sim 300$ m a.s.l), Inn River OC loadings increase, and this is followed by a linear decrease along the Danube mainstem to the delta that forms the interface to the Black Sea.

\subsubsection{Loading increase along the alpine tributary}

The initial increase in OM loadings is most pronounced for the brGDGT soil biomarkers (Fig. 5c), and is consistent with the extent of soil coverage and formation. The highest elevations of the Inn catchment are devoid of soils, and transition to shallow, barely developed soils and then to thicker soil profiles with fully developed A, B and C horizons with decreasing elevation (Fig. 1). Loadings of the higher plant markers (lignin-derived phenols and especially FAs; Figs. 6c and 4c) and of TOC (Fig. 3b) exhibit greater scatter. Lignin is presumably present in varying proportions as discrete woody debris in coarser fractions, as well as in dissolved, and mineral-bound form, likely accounting for the weaker correlation with mineral surface area compared to FAs, which are mainly associated with the mineral phase (Chen and Tarachitzky, 2009; Jex et al., 2014). In contrast to [mineral-bound] plant wax FAs (Wiesenberg et al., 2010), surface runoff of vegetation and litter may be an important vector for supply of lignin to the river (Feng et al., 2013). The scatter of FA loadings in the alpine subcatchment likely partially reflects variability in tributary catchments, gradients in soil development (thickness), as well as higher erosion rates at higher elevations due to steeper slopes and therefore higher energy processes. Since the latter would limit timescales for formation of organomineral associations and enhance the export of coarser (rock) particles with low SA, a greater proportion of OC may be transported as discrete debris and not associated with mineral surfaces. Generally, stochastic erosion processes in high elevations tend to induce a higher variability in signals (Smith et al., 2013). A further consideration is the gradient in vegetation abundance and type within the Inn catchment; Grasses predominate in the highest parts of the catchment above the tree line, and vegetation biomass increases down to the confluence with the Danube, potentially contributing to higher biomolecular and TOC loadings further downstream. Scatter in TOC loadings in the upper Inn catchment (Fig. 3b) likely derive from a relatively OC-rich sedimentary rock formation the Inn incises (Bündnerschiefer; Waibel and Frisch, 1989). Erosion of this material may entrain fossil OC independent of grain size.

\subsubsection{Loading decrease along the Danube mainstem}

The Inn carries about $65 \%$ more water than the Danube mainstem at their confluence (Sommerwerk et al., 2009) and about five times more total suspended solids, which is mainly inorganic in content (ICPDR, 2008). The alpine tributary water mass mixes with the Danube River, with the latter sourced in the Black Forest at lower elevation (ca. $1000 \mathrm{~m}$ a.s.1) and likely carrying a different organic carbon and biomarker signal. From this point onwards, the TOC, FA, brGDGT and lignin loadings decrease linearly with distance downstream (Figs. $3 b$ and 4c, 5c and 6c). Material from well-developed soils is continuously added to the river sediment load. In soils, fresh biomass is preferentially degraded while organic molecules sorbed to minerals, primarily phyllosilicates, are more persistent (von Lützow et al., 2006). However, although the clay content of topsoil in the catchment generally increases from the upper to the lower basin (Fig. A3), the OM loadings on these minerals decrease. This trend is followed by tributaries, which exhibit lower loadings further downstream in the catchment (Fig. $3 b$ and $4 c, 5 c$ and $6 c$ ). This suggests that a more continental climate (ICPDR, 2005) and/or flatter topography in the lower reaches of the catchment (i.e., slower transfer times from the landscape into the river) enhance reworking and degradation of OM in soils, leading to more degraded OC contributing to fluvial sediments. Additionally, erosion of low OC/high SA loess or other pre-Holocene sedimentary rock deposits, mainly in the middle and lower basins (Kostic and Protic, 2000; Haase et al., 2007; Hatte et al., 2013; Zech et al., 2013; Jipa, 2014) likely contribute to the decreasing loadings in Danube sediments. In this context, the distinctive pattern exhibited by the Inn and Danube sediments in Fig. 7 - with upper basin locations at the upper end of the 'typical river sediment' loading range, and lower basin locations at the lower loading end implies that sediments along this large river transect can be envisioned as a gradient of short (fresher OC) to long 
(more degraded OC) exposure times of terrestrial OM to oxic conditions on the landscape (i.e., in soils) and/or during fluvial transport. Thus, projecting loadings within this type of graphical framework (Fig. 7) may prove useful for examination of longitudinal trends in fluvial systems.

The addition of low OC/high SA loess material from middle and lower basin tributaries likely contributes to a decrease in the loadings of Danube mainstem sediments. However, in comparison to the Danube mainstem, the addition of sediment with low OC loadings from these tributaries (especially those in the lower basin) is too small to lower the mainstem loadings to the observed extent (Fig. A4). Another process that potentially could lead to decreasing loadings is POC/DOC exchange and loss of POC into the DOC pool. However, the brGDGT-derived temperature signal in the river sediment changes in line with the local conditions at the sampling locations with no evidence for significant addition of in-river produced brGDGTs, as shown in Freymond et al. (2017). These local brGDGT proxy values in river sediment evolve together with the decrease in loadings (Fig. 8), what speaks against POC/DOC exchange as main process. This rather implies that new material carrying local information is added to the sediment and therefore, at least a portion of the upstream signal has to be removed to produce such a local signal. Furthermore, it is unlikely that highly hydrophobic (and therefore particle-reactive) molecules such as long-chain FAs will accumulate in the dissolved phase whereas it is clear that the mineral-associated concentration decreases. A local plant wax fatty acid signature corresponding to the altitude of the sampling location was also found in the Madre de Dios River, and was partly attributed to degradation and net loss of the upstream signal (Ponton et al., 2014). Therefore, we conclude that degradation processes contribute to the observed decrease in $\mathrm{OC}$ and biomarker loadings in the lower reaches. The large decrease of $\mathrm{OC}(70-80 \%)$ along the river system (Fig. 3b and 4c, 5c and 6c) suggests that not only fresh and free organic carbon is remineralized, but mineralassociated carbon also seems to be degraded during transport. Radiocarbon measurement of TOC for sediment samples from the apex of the delta yielded a ${ }^{14} \mathrm{C}$ age of about 2000 years (Fig. A1e), consistent with protracted entrainment in deposition and resuspension cycles during fluvial transport accompanied by aging and degradation of $\mathrm{OC}$ and/or dilution with pre-aged, low OC loading loess material. The smaller decrease of FA loadings $(70 \%)$ compared to brGDGTs $(81 \%)$ suggests that FAs are more closely associated with SA. Therefore, while organo-mineral interactions likely suppress degradation and to some degree protect mineral-bound OM from remineralization, our findings show that organo-mineral associations within river systems are clearly dynamic and evolve throughout the river network. Further constraints on the composition, provenance and age of specific organic components in river sediment as well as suspended sediment are needed in order to shed further light on the evolution of OM during fluvial transport.

Our study ends at the terminus of the Danube River, and thus the fate of fluvially-derived sedimentary OM upon discharge to the Black Sea remains an open question.

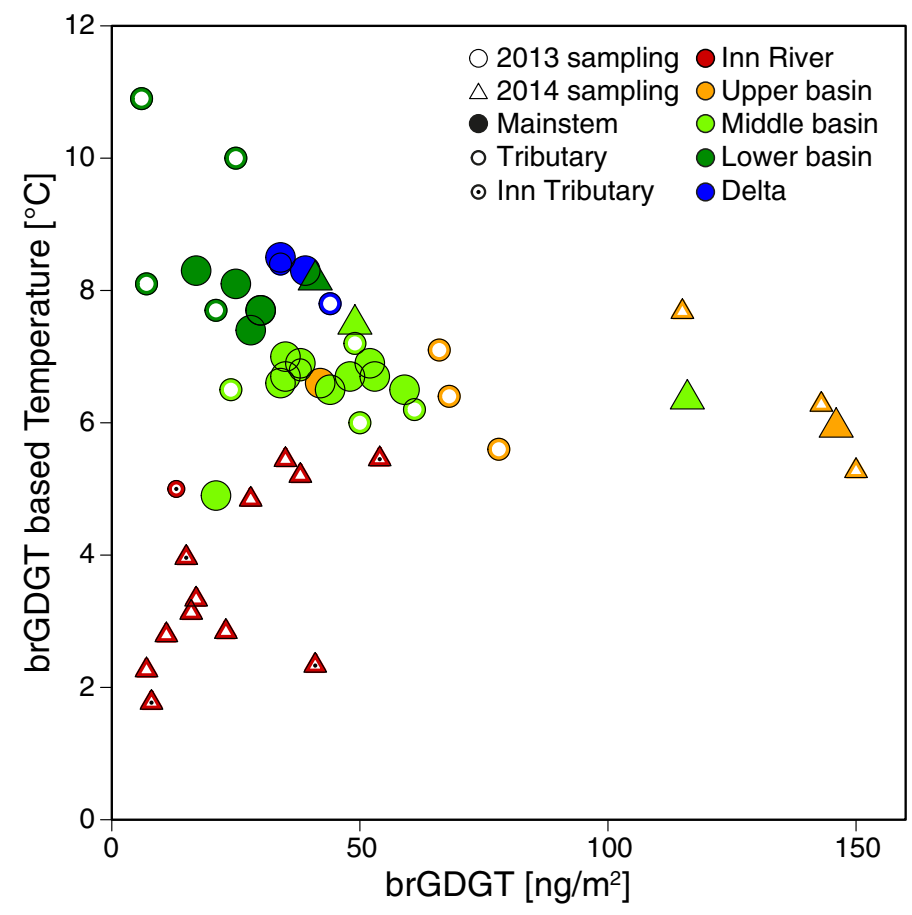

Fig. 8. BrGDGT-based temperature in relation to brGDGT loading. BrGDGT-based temperature data from Freymond et al. (2017). In red, the initial buildup of brGDGT loadings with increasing temperature (and therefore decreasing altitude) is visible, followed by increasing temperatures with decreasing loadings along the Danube mainstem. Symbol color and shape correspond to those in Figs. 1 and 2. (For interpretation of the references to color in this figure legend, the reader is referred to the web version of this article.) 
Nevertheless, the strong decrease in loading over a $2000 \mathrm{~km}$ tract of one of the largest rivers on Earth implies that degradation of particulate OC is significant during transit, and that export of OM from terrigenous primary production to the ocean for such rivers may be dominated by lower basin inputs. In this context, OM preserved in riverdominated shelf sediments may not reflect integrated signals for the entire catchment, but rather is weighted towards its lower reaches, with implications for carbon budgets and interpretation of sedimentary archives.

\section{ACKNOWLEDGEMENTS}

This project was funded by the Swiss National Science Foundation ("CAPS-LOCK" and "CAPS-LOCK2"; \#200021_140850). We thank colleagues who supported both sampling campaigns (Marilu Tavagna, Alissa Zuijdgeest, James Saenz, Stefan Eugen Filip, Silvia Lavinia Filip, Mihai, Clayton Magill, Michael Albani). Further thank goes to Daniel Montluçon, Negar Haghipour and Jennifer Anspach for valuable lab support and Lorena Fischer for ArcGIS-related work. Grain size measurements were performed in the limnogeology lab at ETH Zürich. FP acknowledges funding from ETH Fellowship FEL-36 11-1 and NWO-Veni 863.13.016. All data included in this manuscript can be found in Appendix B. This manuscript benefitted from feedback of three anonymous reviewers.

\section{APPENDIX A. SUPPLEMENTARY MATERIAL}

Supplementary data associated with this article can be found, in the online version, at https://doi.org/10.1016/j. gca.2017.12.010.

\section{REFERENCES}

Baldock J. A. and Skjemstad J. O. (2000) Role of the soil matrix and minerals in protecting natural organic materials against biological attack. Org. Geochem. 31, 697-710.

Bao R., McIntyre C., Zhao M., Zhu C., Kao S. J. and Eglinton T. I. (2016) Widespread dispersal and aging of organic carbon in shallow marginal seas. Geology 44, 791-794.

Bendle J. A., Weijers J. W. H., Maslin M. A., Sinninghe Damsté J. S., Schouten S., Hopmans E. C., Boot C. S. and Pancost R. D. (2010) Major changes in glacial and Holocene terrestrial temperatures and sources of organic carbon recorded in the Amazon fan by tetraether lipids. Geochem. Geophys. Geosyst. 11, 1-13.

Bergmann J. and Kleeberg R. (1998) Rietveld analysis of disordered layer silicates. Mater. Sci. Forum 278-281, 300-305.

Berner R. A. (2006) GEOCARBSULF: a combined model for Phanerozoic atmospheric $\mathrm{O}_{2}$ and $\mathrm{CO}_{2}$. Geochim. Cosmochim. Acta 70, 5653-5664.

Blair N. E. and Aller R. C. (2012) The fate of terrestrial organic carbon in the marine environment. Annu. Rev. Mar. Sci. 4, 401423.

Blair N. E., Leithold E. L. and Aller R. C. (2004) From bedrock to burial: the evolution of particulate organic carbon across coupled watershed-continental margin systems. Mar. Chem. 92, 141-156.

Blöschl G., Nester T., Komma J., Parajka J. and Perdigao R. A. P. (2013) The June 2013 flood in the Upper Danube Basin, and comparisons with the 2002, 1954 and 1899 floods. Hydrol. Earth Syst. Sc. 17, 5197-5212.
Bröder L., Tesi T., Andersson A., Eglinton T. I., Semiletov I. P., Dudarev O. V., Roos P. and Gustafsson Ö. (2016a) Historical records of organic matter supply and degradation status in the East Siberian Sea. Org. Geochem. 91, 16-30.

Bröder L., Tesi T., Salvado J. A., Semiletov I. P., Dudarev O. V. and Gustafsson Ö. (2016b) Fate of terrigenous organic matter across the Laptev Sea from the mouth of the Lena River to the deep sea of the Arctic interior. Biogeosciences 13, 5003-5019.

Burdige D. J. (2005) Burial of terrestrial organic matter in marine sediments: a re-assessment. Global Biogeochem. Cycles 19.

Chen Y. and Tarachitzky J. (2009) Organo-mineral complexes and their effects on the physico-chemical properties of soils. CMS Work. Lect. 16, 32-49.

Chiou C. T., Lee J. F. and Boyd S. A. (1990) The surface area of soil organic matter. Environ. Sci. Technol. 24, 1164-1166.

Chotzen R. A., Polubesova T., Chefetz B. and Mishael Y. G. (2016) Adsorption of soil-derived humic acid by seven clay minerals: a systematic study. Clay Clay Miner. 64, 628-638.

Christl M., Vockenhuber C., Kubik P. W., Wacker L., Lachner J., Alfimov V. and Synal H. A. (2013) The ETH Zurich AMS facilities: performance parameters and reference materials. Nucl. Instrum. Meth. B 294, 29-38.

Coppola L., Gustafsson Ö., Andersson P., Eglinton T. I., Uchida M. and Dickens A. F. (2007) The importance of ultrafine particles as a control on the distribution of organic carbon in Washington Margin and Cascadia Basin sediments. Chem. Geol. 243, 142-156.

Dogan M., Dogan A. U., Yesilyurt F. I., Alaygut D., Buckner I. and Wurster D. E. (2007) Baseline studies of The Clay Minerals Society special clays: specific surface area by the Brunauer Emmett Teller (BET) method. Clay Clay Miner. 55, 534-541.

Downie A., Munroe P. and Crosky A. (2009) Characteristics of biochar: physical and structural properties. In Biochar for environmental management: Science and Technology (eds. J. Lehmann and S. Joseph). Earthscan, London and Sterling, VA, pp. 13-29.

Eglinton T. I. and Eglinton G. (2008) Molecular proxies for paleoclimatology. Earth Planet. Sc. Lett. 275, 1-16.

Feng X. J., Vonk J. E., van Dongen B. E., Gustafsson Ö., Semiletov I. P., Dudarev O. V., Wang Z. H., Montluçon D. B., Wacker L. and Eglinton T. I. (2013) Differential mobilization of terrestrial carbon pools in Eurasian Arctic river basins. Proc. Natl. Acad. Sci. USA 110, 14168-14173.

Freymond C. V., Peterse F., Fischer L. V., Filip F., Giosan L. and Eglinton T. I. (2017) Branched GDGT signals in fluvial sediments of the Danube River basin: method comparison and longitudinal evolution. Org. Geochem. 103, 88-96.

Frings R. M. (2008) Downstream fining in large sand-bed rivers. Earth-Sci. Rev. 87, 39-60.

Galy V., France-Lanord C. and Lartiges B. (2008) Loading and fate of particulate organic carbon from the Himalaya to the GangaBrahmaputra delta. Geochim. Cosmochim. Acta 72, 1767-1787.

Galy V., Eglinton T., France-Lanord C. and Sylva S. (2011) The provenance of vegetation and environmental signatures encoded in vascular plant biomarkers carried by the GangesBrahmaputra rivers. Earth Planet. Sc. Lett. 304, 1-12.

Garzanti E., Ando S. and Vezzoli G. (2009) Grain-size dependence of sediment composition and environmental bias in provenance studies. Earth Planet. Sc. Lett. 277, 422-432.

Goni M. A. and Montgomery S. (2000) Alkaline CuO oxidation with a microwave digestion system: lignin analyses of geochemical samples. Anal. Chem. 72, 3116-3121.

Goni M. A., Teixeira M. J. and Perkey D. W. (2003) Sources and distribution of organic matter in a river-dominated estuary (Winyah Bay, SC, USA). Estuar. Coast. Shelf Sci. 57, 10231048. 
Goni M. A., Yunker M. B., Macdonald R. W. and Eglinton T. I. (2005) The supply and preservation of ancient and modern components of organic carbon in the Canadian Beaufort Shelf of the Arctic Ocean. Mar. Chem. 93, 53-73.

Goni M. A., O'Connor A. E., Kuzyk Z. Z., Yunker M. B., Gobeil C. and Macdonald R. W. (2013) Distribution and sources of organic matter in surface marine sediments across the North American Arctic margin. J. Geophys. Res-Oceans 118, 40174035.

Grams C. M., Binder H., Pfahl S., Piaget N. and Wernli H. (2014) Atmospheric processes triggering the central European floods in June 2013. Nat. Hazards Earth Syst. Sci. 14, 1691-1702.

Griepentrog M., Eglinton T. I., Hagedorn F., Schmidt M. W. I. and Wiesenberg G. L. B. (2015) Interactive effects of elevated $\mathrm{CO}_{2}$ and nitrogen deposition on fatty acid molecular and isotope composition of above- and belowground tree biomass and forest soil fractions. Glob. Change Biol. 21, 473-486.

Haase D., Fink J., Haase G., Ruske R., Pecsi M., Richter H., Altermann M. and Jager K. D. (2007) Loess in Europe - its spatial distribution based on a European Loess Map, scale 1:2,500,000. Quaternary Sci. Rev. 26, 1301-1312.

Hatte C., Gauthier C., Rousseau D. D., Antoine P., Fuchs M., Lagroix F., Markovic S. B., Moine O. and Sima A. (2013) Excursions to $\mathrm{C} 4$ vegetation recorded in the Upper Pleistocene loess of Surduk (Northern Serbia): an organic isotope geochemistry study. Clim. Past 9, 1001-1014.

Hedges J. I. and Keil R. G. (1995) Sedimentary organic-matter preservation: an assessment and speculative synthesis. Mar. Chem. 49, 81-115.

Hedges J. I. and Stern J. H. (1984) Carbon and nitrogen determinations of carbonate-containing solids. Limnol. Oceanogr. 29, 657-663.

Hemingway J. D., Rothman D. H., Rosengard S. Z. and Galy V. V. (2017) Technical note: an inverse method to relate organic carbon reactivity to isotope composition from serial oxidation. Biogeosciences 14, 5099-5114.

ICPDR (2005) The Danube River Basin District. Part A - Basinwide Overview (ed. U. Schmedtje). International Commission for the Protection of the Danube River, ICPDR.

ICPDR (2008) Joint Danube Survey 2. Final Scientific Report. International Commission for the Protection of the Danube River, ICPDR.

ICPDR (2014) Floods in June 2013 in the Danube River Basin. Brief Overview of Key Events and Lessons Learned. International Commission for the Protection of the Danube River, ICPDR.

ICPDR \& ISRBC (2015) Floods in May 2014 in the Sava River Basin. Brief overview of key events and lessons learned. International Commission for the Protection of the Danube River, ICPDR and International Sava River Basin Commission, ISRBC.

JDS3 (2013) Danubis, the ICPDR information system - Danube river basin water quality database.

Jex C. N., Pate G. H., Blyth A. J., Spencer R. G. M., Hernes P. J., Kahn S. J. and Baker A. (2014) Lignin biogeochemistry: from modern processes to Quaternary achieves. Quaternary Sci. Rev. 87, 46-59.

Jipa D. C. (2014) The conceptual sedimentary model of the Lower Danube loess basin: sedimentogenetic implications. Quat. Int. 351, 14-24.

Kastner T. P. and Goni M. A. (2003) Constancy in the vegetation of the Amazon Basin during the late Pleistocene: evidence from the organic matter composition of Amazon deep sea fan sediments. Geology 31, 291-294.

Kaufhold S., Dohrmann R., Klinkenberg M., Siegesmund S. and Ufer K. (2010) N2-BET specific surface area of bentonites. $J$. Colloids Interf. Sci. 349, 275-282.
Keil R. G. and Mayer L. M. (2014) Mineral matrices and organic matter. In Treatise on Geochemistry (ed. K. K. Turekian), second ed. Elsevier, Oxford, pp. 337-359.

Keil R. G., Tsamakis E., Fuh C. B., Giddings J. C. and Hedges J. I. (1994) Mineralogical and textural controls on the organic composition of coastal marine sediments: hydrodynamic separation using SPLITT-fractionation. Geochim. Cosmochim. Acta 58, 879-893.

Keil R. G., Mayer L. M., Quay P. D., Richey J. E. and Hedges J. I. (1997) Loss of organic matter from riverine particles in deltas. Geochim. Cosmochim. Acta 61, 1507-1511.

Komada T., Anderson M. R. and Dorfmeier C. L. (2008) Carbonate removal from coastal sediments for the determination of organic carbon and its isotopic signatures, delta C-13 and Delta C-14: comparison of fumigation and direct acidification by hydrochloric acid. Limnol. Oceanogr.: Meth. 6, 254 262.

Kostic N. and Protic N. (2000) Pedology and mineralogy of loess profiles at Kapela-Batajnica and Stalac, Serbia. Catena 41, 217227.

Ludwig W., Probst J. L. and Kempe S. (1996) Predicting the oceanic input of organic carbon by continental erosion. Global Biogeochem. Cycles 10, 23-41.

Martin J. M. and Meybeck M. (1979) Elemental mass-balance of material carried by major world rivers. Mar. Chem. 7, 173-206.

Masiello C. A. (2004) New directions in black carbon organic geochemistry. Mar. Chem. 92, 201-213.

Mayer L. M. (1994) Surface-area control of organic-carbon accumulation in continental-shelf sediments. Geochim. Cosmochim. Acta 58, 1271-1284.

Mayer L. M., Macko S. A. and Cammen L. (1988) Provenance, concentrations and nature of sedimentary organic nitrogen in the Gulf of Maine. Mar. Chem. 25, 291-304.

McIntyre C. P., Wacker L., Haghipour N., Blattmann T. M., Fahrni S., Usman M., Eglinton T. I. and Synal H. A. (2016) Online ${ }^{13} \mathrm{C}$ and ${ }^{14} \mathrm{C}$ gas measurements by EA-IRMS-AMS at ETH Zürich. Radiocarbon, 1-11.

Nemec M., Wacker L. and Gaggeler H. (2010) Optimization of the graphitization process at AGE-1. Radiocarbon 52, 13801393.

Nguyen T. T. and Marschner P. (2016) Sorption of waterextractable organic carbon in various clay subsoils: effects of soil properties. Pedosphere 26, 55-61.

Noyan H., Önal M. and Sarikaya Y. (2006) The effect of heating on the surface area, porosity and surface acidity of a bentonite. Clay Clay Miner. 54, 375-381.

Pennell K. D., Abriola L. M. and Boyd S. A. (1995) Surface area of soil organic matter reexamined. Soil Sci. Soc. Am. J. 59, 10121018.

Plesingerova B., Sucik G. and Fabian M. (2011) Surface area change of kaolin causing annealing. Acta Matallurgica Slovaca 17, 169-176.

Ponton C., West A. J., Feakins S. J. and Galy V. (2014) Leaf wax biomarkers in transit record river catchment composition. Geophys. Res. Lett. 41, 6420-6427.

Ransom B., Kim D., Kastner M. and Wainwright S. (1998) Organic matter preservation on continental slopes: importance of mineralogy and surface area. Geochim. Cosmochim. Acta 62, $1329-1345$.

R Core Team (2014) R: A Language and Environment for Statistical Computing. R Foundation for Statistical Computing, Vienna, Austria.

Saidy A. R., Smernik R. J., Baldock J. A., Kaiser K. and Sanderman J. (2013) The sorption of organic carbon onto differing clay minerals in the presence and absence of hydrous iron oxide. Geoderma 209-210, 15-21. 
Sanchi L., Ménot G. and Bard E. (2014) Insights into continental temperatures in the northwestern Black Sea area during the Last Glacial period using branched tetraether lipids. Quaternary Sci. Rev. 84, 98-108.

Schefuss E., Schouten S. and Schneider R. R. (2005) Climatic controls on central African hydrology during the past 20,000 years. Nature 437, 1003-1006.

Schiller H., Miklós D. and Sass J. (2010) The Danube River and its basin physical characteristics, water regime and water balance. In Hydrological processes of the Danube River Basin. Perspectives from the Danubian (ed. B. Mitja). Springer, Dordrecht, Netherlands, pp. 25-77.

Schouten S., Huguet C., Hopmans E. C., Kienhuis M. V. M. and Sinninghe Damsté J. S. (2007) Analytical methodology for TEX86 paleothermometry by high-performance liquid chromatography/atmospheric pressure chemical ionization-mass spectrometry. Anal. Chem. 79, 2940-2944.

Schouten S., Hopmans E. C. and Sinninghe Damsté J. S. (2013) The organic geochemistry of glycerol dialkyl glycerol tetraether lipids: a review. Org. Geochem. 54, 19-61.

Singh M., Sarkar B., Biswas B., Churchman J. and Bolan N. S. (2016) Adsorption-desorption behavior of dissolved organic carbon by soil clay fractions of varying mineralogy. Geoderma 280, 47-56.

Smith J. C., Galy A., Hovius N., Tye A. M., Turowski J. M. and Schleppi P. (2013) Runoff-driven export of particulate organic carbon from soil in temperate forested uplands. Earth Planet. Sc. Lett. 365, 198-208.

Sommerwerk N., Hein T., Scheider-Jakoby M., Baumgartner C., Ostojic A., Paunovic M., Bloesch J., Sieber R. and Tockner K. (2009) The Danube River basin. In Rivers of Europe (eds. K. Tockner, U. Uehlinger and C. T. Robinson). Elsevier Science, London, pp. 59-112.

Sorensen L. H. (1981) Carbon-nitrogen relationships during the humification of cellulose in soils containing different amounts of clay. Soil Biol. Biochem. 13, 313-321.

Synal H. A., Stocker M. and Suter M. (2007) MICADAS: a new compact radiocarbon AMS system. Nucl. Instrum. Meth. B 259, 7-13.

Tao S. Q., Eglinton T. I., Montluçon D. B., McIntyre C. and Zhao M. X. (2015) Pre-aged soil organic carbon as a major component of the Yellow River suspended load: regional significance and global relevance. Earth Planet. Sc. Lett. 414, $77-86$.

Tesi T., Semiletov I., Hugelius G., Dudarev O., Kuhry P. and Gustafsson Ö. (2014) Composition and fate of terrigenous organic matter along the Arctic land-ocean continuum in East Siberia: insights from biomarkers and carbon isotopes. Geochim. Cosmochim. Acta 133, 235-256.

Tesi T., Semiletov I., Dudarev O., Andersson A. and Gustafsson Ö. (2016) Matrix association effects on hydrodynamic sorting and degradation of terrestrial organic matter during cross-shelf transport in the Laptev and East Siberian shelf seas. J. Geophys. Res-Biogeo. 121, 731-752.
Thevenot M., Dignac M. F. and Rumpel C. (2010) Fate of lignins in soils: a review. Soil Biol. Biochem. 42, 1200-1211.

Torn M. S., Trumbore S. E., Chadwick O. A., Vitousek P. M. and Hendricks D. M. (1997) Mineral control of soil organic carbon storage and turnover. Nature 389, 170-173.

Valter M. and Plötze M. (2013) Characteristics of variably saturated granular bentonite after long-term storage at nearfield relevant temperatures. Clay Miner. 48, 343-361.

Vogel C., Heister K., Buegger F., Tanuwidjaja I., Haug S., Schloter M. and Kögel-Knabner I. (2015) Clay mineral composition modifies decomposition and sequestration of organic carbon and nitrogen in fine soil fractions. Biol. Fert. Soils 51, 427-442.

Von Lützow M., Kögel-Knabner I., Ekschmitt K., Matzner E., Guggenberger G., Marschner B. and Flessa H. (2006) Stabilization of organic matter in temperate soils: mechanisms and their relevance under different soil conditions - a review. Eur. $J$. Soil Sci. 57, 426-445.

Vonk J. E., Giosan L., Blusztajn J., Montluçon D., Pannatier E. G., McIntyre C., Wacker L., Macdonald R. W., Yunker M. B. and Eglinton T. I. (2015) Spatial variations in geochemical characteristics of the modern Mackenzie Delta sedimentary system. Geochim. Cosmochim. Acta 171, 100-120.

Wacker L., Nemec M. and Bourquin J. (2010) A revolutionary graphitisation system: fully automated, compact and simple. Nucl. Instrum. Meth. B 268, 931-934.

Waibel A. F. and Frisch W. (1989) The Lower Engadine Window: sediment deposition and accretion in relation to the platetectonic evolution of the Eastern Alps. Tectonophysics 162, 229-241.

Wakeham S. G., Canuel E. A., Lerberg E. J., Mason P., Sampere T. P. and Bianchi T. S. (2009) Partitioning of organic matter in continental margin sediments among density fractions. Mar. Chem. 115, 211-225.

Weijers J. W. H., Schefuss E., Schouten S. and Sinninghe Damsté J. S. (2007) Coupled thermal and hydrological evolution of tropical Africa over the last deglaciation. Science 315, 17011704.

Wiesenberg G. L. B., Dorodnikov M. and Kuzyakov Y. (2010) Source determination of lipids in bulk soil and soil density fractions after four years of wheat cropping. Geoderma 156, 267-277.

Zech R., Zech M., Markovic S., Hambach U. and Huang Y. (2013) Humid glacials, arid interglacials? Critical thoughts on pedogenesis and paleoclimate based on multi-proxy analyses of the loess-paleosol sequence Crvenka, Northern Serbia. Palaeogeogr. Palaeocl. 387, 165-175.

Zhang G. P., Germaine J. T., Martin R. T. and Whittle A. J. (2003) A simple sample-mounting method for random powder X-ray diffraction. Clay Clay Miner. 51, 218-225.

Associate editor: Josef P. Werne 